\title{
Faktor Peramal Penerimaan Perkhidmatan e-Kerajaan
}

\author{
SYAFILA KAMARUDIN \\ SITI ZOBIDAH OMAR \\ Universiti Putra Malaysia
}

\begin{abstract}
ABSTRAK
E-kerajaan dibangunkan untuk mengubah cara operasi dalam kerajaan dengan menggunakan sistem penyampaian perkhidmatan dalam talian. Justeru, kajian ini memberi fokus kepada salah satu perkhidmatan e-kerajaan iaitu aplikasi MyEG. Kajian ini bertujuan untuk meneroka faktor peramal yang mempengaruhi penerimaan pengguna terhadap perkhidmatan aplikasi MyEG. Faktor tersebut terdiri daripada empat konstruk utama iaitu pengaruh sosial, jangkaan prestasi, jangkaan usaha dan suasana dorong. Manakala bagi pemboleh ubah bersandar kajian ialah penerimaan aplikasi MyEG. Pendekatan kuantitatif melalui kaedah tinjauan menggunakan borang soal selidik digunakan. Seramai 396 pengguna aplikasi MyEG di sekitar kawasan Lembah Klang dipilih sebagai responden kajian. Kesemua data dianalisis menggunakan perisian SPSS versi 22. Teknik persampelan kajian ialah persampelan rawak mudah dan bertujuan. Dua prosedur statistik telah digunakan iaitu statistik deskriptif dan statistik inferensi. Hasil keputusan menunjukkan bahawa tahap penerimaan pengguna terhadap aplikasi MyEG berada pada tahap sederhana. Ujian korelasi Pearson membuktikan bahawa terdapat hubungan yang positif dan signifikan antara jangkaan prestasi, jangkaan usaha, suasana dorong dan pengaruh sosial terhadap penerimaan aplikasi MyEG. Aplikasi MyEG diterima oleh pengguna kerana aplikasi ini mementingkan faktor persekitaran dalam penggunaannya. Manakala ujian multi regresi mendapati jangkaan prestasi, suasana dorong, pengaruh sosial dan jangkaan usaha merupakan pemboleh ubah peramal kepada penerimaan aplikasi MyEG. Namun begitu, jangkaan prestasi adalah faktor utama yang menyumbang kepada penerimaan aplikasi MyEG oleh pengguna.
\end{abstract}

Kata kunci: e-kerajaan, perkhidmatan dalam talian, aplikasi, faktor peramal, penerimaan.

\section{Predictor Factors Towards Acceptance of e-Government Services}

\begin{abstract}
The e-government application was developed to change the way the government operates in the online service delivery system. Thus, this study focused on one of the e-government platforms namely, the MyEG application. This study was aimed to determine the predictor factors that influence consumers' acceptance using the MyEG application. The framework consisted of four main predictors namely, social influence, performance expectancy, effort expectancy and facilitating conditions, while the dependent variable was the acceptance of MyEG application. A quantitative approach was adopted, by using a questionnaire survey. A total of 396 MyEG application users in the Klang Valley were selected to participate in the survey. The data collected were analyzed using SPSS version 22. Two sampling techniques were used; simple random and purposive. Two statistics procedures were used; descriptive and inferential. The results displayed that the level of acceptance towards the MyEG application was at a moderate level. The Pearson correlation test also revealed a positive and significant correlation between performance expectancy, effort expectancy, facilities condition and social influences to the acceptance of MyEG application. The analysis showed that users had accepted the MyEG application because it was emphasized the predictor factors. Moreover, the multi regression test found that performance expectancy, facilities conditions, social influences and effort expectancy
\end{abstract}


were among the variables that predicted the acceptance of the MyEG application. However, the overall result showed that performance expectancy was a major factor that contributed to the acceptance of the MyEG application among users.

Keywords: e-government, online services, application, predictor factor, acceptance

\section{PENGENALAN}

E-kerajaan adalah satu bentuk anjakan operasi perkhidmatan awam daripada tradisional kepada yang lebih moden (Muhammad Rais \& Nazariah, 2003). Dalam menjayakan perkhidmatan ini, kehadiran teknologi maklumat dan komunikasi (ICT) adalah amat penting supaya pelaksanaan perkhidmatan tersebut dapat dijayakan dengan sebaiknya dan dimanfaatkan oleh pengguna (Hazita Azman et al., 2014). Kewujudan ICT bukan sahaja membantu pengurusan e-kerajaan, malah turut memberi kemudahan kepada pelbagai aspek yang lain seperti ekonomi (Doucek et al., 2014; Mohd Nizam, 2018), pendidikan (Andre et al., 2018; Bett et al., 2014), sistem pengurusan hospital (Waring \& Wainwright, 2002; Nik Adzrieman, 2017) dan lain-lain.

Terdapat empat objektif e-kerajaan ditubuhkan (Almarabeh \& Abu Ali, 2010). Pertama, e-kerajaan menawarkan pentadbiran perkhidmatan secara dalam talian yang lebih berkualiti tinggi dan cekap khusus untuk rakyat dan golongan perniagaan. Kedua, e-kerajaan menyelaraskan semua proses dalaman kerajaan supaya dapat meningkatkan kualiti perkhidmatan, mengurangkan kos dan meningkatkan produktiviti. Ketiga, e-kerajaan dapat mempertingkatkan keselamatan data dan mempertahankan privasi. Keempat, e-kerajaan membantu meningkatkan penyertaan rakyat dalam berurusan dengan pihak kerajaan. Berpandukan kepada objektif e-kerajaan ini, adalah menjadi tanggungjawab pihak kerajaan untuk memastikan sistem penyampaian perkhidmatan dapat dicapai dan digunakan oleh semua masyarakat walau di mana jua mereka berada (Hasmiah et al., 2013).

Menurut Norshita et al. (2010), e-kerajaan dibangunkan mengikut dua fasa. Fasa pertama, tumpuan diberikan kepada proses dalaman agensi dengan tujuan untuk melicin dan meningkatkan keupayaan serta kecekapan dan keberkesanan agensi dalam menyediakan perkhidmatan. Fasa kedua, penumpuan terhadap usaha untuk meningkatkan pencapaian perkhidmatan yang ditawarkan oleh agensi kerajaan kepada orang ramai serta ahli perniagaan melalui pelbagai saluran elektronik. Ini jelas menunjukkan bahawa melalui e-kerajaan, segala bentuk urusan perkhidmatan dengan pihak kerajaan dapat diselesaikan dengan menggunakan sistem perkhidmatan dalam talian (Kaylor et al., 2002). Seperti yang disasarkan oleh pihak kerajaan pada tahun 2015 yang lalu, sebanyak 90 peratus daripada sistem penyampaian perkhidmatan awam ditawarkan secara dalam talian (Nor Aliah, 2011) dan salah satu arah tuju polisi ICT sektor awam tersebut untuk menjadikan sistem penyampaian perkhidmatan menuju ke arah sifar bersemuka (Hasmiah et al., 2013).

Projek e-kerajaan bermula apabila kerajaan melancarkan Koridor Raya Multimedia (MSC). Pelbagai perubahan dapat dilihat di sepanjang tempoh pelancaran e-kerajaan ini. Misalnya, pembaharuan dalam servis di peringkat jabatan dan agensi kerajaan terutamanya yang melibatkan perkhidmatan kaunter dan orang ramai (Ahmad et al., 2012). Rakyat diseru agar menggunakan sistem dalam talian bagi memudahkan urusan mereka dengan pihak kerajaan (Norashuha et al., 2013). Justeru, sehingga kini penambahbaikan terus dijalankan dan dipantau dari semasa ke semasa sejajar dengan keperluan masyarakat yang menuntut kepada kepantasan masa. 
Kajian lalu banyak membincangkan isu mengenai penggunaan e-kerajaan dari pelbagai bentuk aplikasi kerajaan. Sebagai contoh, Norashikin et al. (2011) menjalankan penyelidikan e-kerajaan mengenai budaya e-pengguna dalam kalangan rakyat Malaysia. Para penyelidik ini telah melihat tahap keperluan e-pengguna terhadap sistem e-kerajaan Malaysia. Begitu juga Maizatul Haizan et al. (2012) yang menjalankan penyelidikan empirik mengenai inovasi perkhidmatan awam Malaysia melalui pelaksanaan e-kerajaan. Kajian tersebut memberi fokus tentang penerimaan e-servis di Lembah Klang. Selain itu, kajian Hung et al. (2006) meneliti pemfailan cukai dalam talian dan sistem pembayaran oleh masyarakat di Taiwan. Oleh itu, penyelidikan ini memberi fokus kepada salah satu sistem e-kerajaan iaitu Kerajaan Elektronik Malaysia (MyEG).

\section{SOROTAN LITERATUR}

MyEG merupakan aplikasi yang menggunakan perkhidmatan secara dalam talian. Tujuan aplikasi MyEG ditubuhkan untuk memberi kemudahan kepada masyarakat mendapat perkhidmatan yang ditawarkan melalui sistem dalam talian (Hasmiah et al., 2011). Menurut Rust dan Lemon (2001), perkhidmatan berasaskan dalam talian adalah suatu penyediaan perkhidmatan melalui rangkaian elektronik dan penggunaannya semakin mendapat perhatian daripada pelbagai pihak.

Akibat dari perubahan cara berurusan dengan pihak pembekal perkhidmatan iaitu dari perkhidmatan kaunter kepada dalam talian, maka pelbagai impak terhasil untuk kedua-dua belah pihak iaitu pengguna dan pembekal perkhidmatan. Kajian Noraidah et al. (2011) mendapati penggunaan sistem dalam talian dapat meningkatkan kecekapan pengguna, keberkesanan sistem dan kemantapan perkhidmatan awam selaras dengan matlamat negara. Di samping itu juga, penggunaan perkhidmatan dalam talian dapat membantu masyarakat menyelesaikan urusan dengan lebih pantas (Ozgen \& Turan, 2007).

Kajian Norashuha et al. (2013) turut menjelaskan bahawa penggunaan perkhidmatan dalam talian dapat mengurangkan keperluan bersemuka. Dengan ini, pengguna dapat menjimatkan masa (Conrad, 2009) terutama bagi pengguna yang sibuk dengan tugasan lain. Sekiranya pengguna menggunakan perkhidmatan kaunter misalnya, mereka terpaksa mengikut masa yang telah ditetapkan iaitu berurusan ketika masa pejabat sahaja. Kajian lalu menunjukkan dengan menggunakan aplikasi dalam talian masyarakat akan memperoleh manfaat dari sistem penyampaian perkhidmatan tersebut seperti urusan dapat diselesaikan dengan cepat dan mudah (Mohd Safar \& Ali, 2010). Ini disokong dalam kajian Maizatul Haizan et al. (2011) menyatakan bahawa pengguna aplikasi dalam talian boleh melayari dan menggunakan laman sesawang pembekal perkhidmatan pada bila-bila masa sahaja dan ia memudahkan pengguna.

Aplikasi MyEG juga membantu pembangunan masyarakat setempat dan penyelidik seperti Zulkefli \& Ainin (2009) menyatakan kebanyakan masyarakat Malaysia memperolehi maklumat mengenai pembekal perkhidmatan kerajaan dan hal-hal semasa adalah melalui sistem dalam talian. Jelas di sini peranan perkhidmatan dalam talian dapat membentuk masyarakat supaya menggunakan teknologi baharu. Masyarakat melihat penggunaan aplikasi MyEG sebagai alat untuk mereka menjalankan sebarang bentuk urusan. Keadaan ini memberikan kemudahan kepada semua rakyat yang menggunakannya walau di mana mereka berada (Hamizah et al., 2014). 
Walaupun pelbagai kelebihan dapat diperoleh dengan menggunakan aplikasi dalam talian ini, kajian lalu turut menyatakan bahawa penggunaan sistem dalam talian perlu dipertingkatkan dari semasa ke semasa (Hasmiah et al., 2013). Misalnya, statistik yang dikeluarkan oleh MAMPU (2011) menunjukkan jumlah urusniaga melalui perkhidmatan dalam talian hanya mencapai $43 \%$ daripada jumlah urusniaga perkhidmatan awam yang dibuat (Nor Aliah, 2012). Selebihnya pengguna masih melakukan perkhidmatan secara e-kaunter (35\%), campuran (14\%) dan kaunter manual (8\%). Melalui statistik ini, penggunaan perkhidmatan dalam talian masih belum digunakan sepenuhnya oleh masyarakat. Dikatakan ada segelintir masyarakat masih teragak-agak untuk menggunakan sistem dalam talian (Gummerus et al., 2004). Keadaan ini menyebabkan mereka berbalik semula kepada kaedah tradisional.

\section{Konstruk Faktor Peramal}

Konstruk faktor peramal adalah penting bagi mengukur tahap penerimaan pengguna aplikasi MyEG. Konstruk-konstruk tersebut dijadikan asas dalam memberi gambaran secara umum mengenai faktor yang mempengaruhi individu terhadap penerimaan dan penggunaan aplikasi MyEG. Bagi menentukan konstruk faktor peramal, beberapa model dan teori telah dikenal pasti memiliki konstruk yang telah diuji terhadap penerimaan dan penggunaan teknologi baharu. Antara konstruk tersebut termasuklah jangkaan prestasi, jangkaan usaha, pengaruh sosial, suasana dorong, sikap terhadap tingkah laku, norma subjektif, kawalan tingkah laku yang dirasakan, kesesuaian kerja, kebergunaan, kemudahgunaan, dan lain-lain. Untuk kajian ini, penyelidik telah menggunakan konstruk faktor peramal dari model Unified Theory of Acceptance and Use of Technology (UTAUT) (Venkatesh et al., 2003) iaitu jangkaan prestasi, jangkaan usaha, pengaruh sosial dan suasana dorong. Dalam menerangkan variasi pengguna terhadap teknologi baharu, konstruk UTAUT telah terbukti lebih berjaya jika dibandingkan dengan konstruk daripada teori dan model yang lain. Maka dengan itu, kajian ini memilih konstruk daripada UTAUT bagi menguji dan meramal keberkesanannya terhadap penerimaan dan penggunaan aplikasi MyEG.

\section{a. Jangkaan Prestasi}

Jangkaan prestasi merupakan tahap keyakinan diri seseorang dalam menggunakan teknologi. Ini bermaksud dengan menggunakan aplikasi MyEG maka pengguna dapat menghasilkan prestasi kerja yang cemerlang dan maksimum. Menurut Venkatesh et al. (2003), jangkaan prestasi ialah sejauh mana individu percaya dengan menggunakan sistem akan membantu mereka untuk memperoleh keuntungan dalam prestasi kerja.

Ini disokong oleh Prasetyo dan Anubhakti (2011) tentang penerimaan sistem epembelajaran pelajar di Universitas Budi Luhur, Indonesia. Mereka menjelaskan sikap yang ditonjolkan mempengaruhi pengguna untuk menggunakan e-pembelajaran. Mereka menambah faktor jangkaan prestasi dapat membina harapan pengguna bahawa dengan menggunakan sistem e-pembelajaran maka pengguna dapat menghasilkan kerja yang optimum. Namun demikian, kajian Rahmatika (2015) menolak kenyataan di atas dengan menjelaskan bahawa jangkaan prestasi tidak berpengaruh terhadap penerimaan dan penggunaan Corel Draw untuk pembelajaran multimedia. Beliau menambah, pengguna tidak yakin akan kemampuan dirinya sendiri dalam menggunakan Corel Draw tersebut. Ini membuktikan faktor keyakinan diri dalam diri seseorang turut mempengaruhi jangkaan prestasi yang dipamerkan oleh pengguna. 
Manakala Marchewka et al. (2007) dalam kajian berkenaan 'Student Perceptions Using Course Management Software' menyatakan walaupun model UTAUT menegaskan jangkaan prestasi boleh menjadi signifikan dalam menentukan penerimaan pengguna terhadap teknologi maklumat, tetapi kebimbangan untuk mudah digunakan (ease of use) boleh menjadi tidak signifikan ke atas penggunaan lanjutan dan berterusan bagi kajian yang dijalankan oleh mereka ini. Para penyelidik ini menjadikan faktor mudah digunakan sebagai penentu kepada jangkaan prestasi pengguna. Apabila kebimbangan pengguna terhadap penggunaan teknologi melebihi faedah yang dijangkakan, maka ia menyebabkan prestasi pengguna untuk menggunakan teknologi menurun. Oleh itu, dapat dirumuskan jangkaan prestasi adalah salah satu faktor yang boleh dibincangkan dengan lebih mendalam dan diuji keberkesanannya terhadap penerimaan aplikasi MyEG.

\section{b. Jangkaan Usaha}

Jangkaan usaha merupakan tahap mudah yang berkaitan dengan penggunaan sesebuah sistem. Carlsson (2006) menyatakan bahawa jangkaan usaha adalah faktor penentu bagi penggunaan sebenar suatu perkhidmatan dalam talian. Kajian Venkatesh et al. (2003) mendapati semakin lama pengguna menggunakan sistem maklumat, semakin yakin mereka ke arah sistem maklumat tersebut. DeLone (1988) turut mendakwa, peningkatan penggunaan secara langsung sistem maklumat akan meningkatkan keyakinan pengguna dalam keupayaan mereka untuk memahami dan menggunakan sistem maklumat ketika melaksanakan tugastugas mereka.

Sebelum ini, kajian secara empirikal bagi penerimaan perbankan mudah alih oleh para penyelidik dahulu seperti Luarn \& Lin (2005); Amin et al., (2008); Puschel et al., (2010); Sripalawat et al., (2011); Dasgupta et al., (2011) dilihat menyokong faktor mudah digunakan sebagai kesan penentu bagi orang ramai untuk menggunakan sistem perbankan mudah alih. Park et al. (2007) dan Lu et al. (2009) telah menggunakan tiga konstruk daripada UTAUT iaitu jangkaan prestasi, jangkaan usaha dan pengaruh sosial untuk meneroka konstruk yang mempengaruhi niat individu untuk menerima teknologi mudah alih dan perkhidmatan data masing-masing. Kedua-dua kajian menyokong faktor jangkaan usaha adalah yang paling ketara mempengaruhi niat manusia untuk menggunakan teknologi. Justeru, dapat dirumuskan bahawa faktor jangkaan usaha juga berfungsi sebagai satu lagi faktor peramal kepada penerimaan atau penolakan masyarakat terhadap aplikasi MyEG.

\section{c. Pengaruh Sosial}

Pengaruh sosial ditakrifkan sebagai sejauh mana seseorang individu menganggap orang lain sebagai penting dalam mempengaruhi mereka supaya percaya untuk menggunakan sistem baharu seperti aplikasi MyEG. Orang lain yang dimaksudkan di sini ialah mereka yang rapat dengan pengguna aplikasi MyEG seperti ahli keluarga dan rakan-rakan.

Kaji selidik yang dijalankan Amin et al. (2008) ke atas 158 pelanggan dari bank utama di Malaysia mendapati bahawa, niat individu untuk menggunakan perbankan mudah alih adalah signifikan dengan orang di sekeliling mereka. Kajian Singh et al. (2010) turut mendapati keputusan individu untuk menerima pakai perkhidmatan perdagangan mudah alih adalah dipengaruhi oleh rakan-rakan dan ahli keluarga.

Kajian Michael dan Prabowo (2011) berkenaan "Kajian Unified Theory of Acceptance and Use of Technology dalam Penggunaan Open Source Software Database Management System" turut mendapati pengaruh sosial sangat mempengaruhi sikap seseorang individu 
terhadap penggunaan teknologi baharu. Oleh yang demikian, dapat dirumuskan pengaruh sosial juga boleh dijadikan faktor peramal bagi menentukan keberkesanannya terhadap penerimaan aplikasi MyEG oleh masyarakat.

\section{d. Suasana Dorong}

Faktor terakhir ialah suasana dorong. Menurut Venkatesh et al. (2003), suasana dorong ditakrifkan sebagai keadaan yang memudahkan sejauh mana individu percaya bahawa infrastruktur organisasi dan teknikal wujud untuk menyokong penggunaan sesebuah sistem seperti aplikasi MyEG. Menurut penyelidik ini, niat tingkah laku dan suasana dorong adalah dua penentu langsung bagi tingkah laku penerimaan teknologi baharu.

Menurut fahaman Triandis (1979), suasana dorong adalah tahap dan jenis sokongan yang diberikan kepada individu yang mempengaruhi penggunaannya terhadap teknologi. Dalam konteks penggunaan teknologi di tempat kerja (Lu et al., 2004), suasana dorong adalah seperti latihan dan penyediaan sokongan. Pemboleh ubah ini telah diuji dalam beberapa kajian penerimaan teknologi dan sokongan empirikal ditemui pada kesan yang dicadangkan pada tanggapan kebergunaan dan tanggapan mudah digunakan (Jiang et al., 2000; Taylor \& Todd, 1995; Thompson et al., 1994; Venkatesh \& Davis, 2000).

Suasana dorong juga telah dikenal pasti mempunyai kesan ke atas kemasukan atau penggunaan beberapa inovasi baharu sistem maklumat (Cheung \& Chang, 2000; Jones et al., 2002). Satu kajian mengenai penggunaan perkhidmatan WAP di Taiwan sebagai kandungan penting perdagangan mudah alih juga mendedahkan suasana dorong sebagai syarat utama bagi faktor kritikal yang mempengaruhi tingkah laku penerimaan bagi perkhidmatan WAP (Hung et al., 2003).

Dalam literatur penggunaan perbankan mudah alih pula, Joshua dan Koshy (2011) menggambarkan bahawa semakin mudah akses pengguna kepada komputer dan Internet, maka lebih mahir penggunaan mereka terhadap komputer dan Internet. Hal ini menyebabkan kadar penggunaan yang lebih tinggi daripada kalangan masyarakat ketika menggunakan perbankan elektronik. Maka, melalui perbincangan literatur ini dapat diandaikan kewujudan konstruk suasana dorong boleh memberi implikasi kepada penerimaan atau penolakan aplikasi MyEG oleh masyarakat di Malaysia.

\section{Penerimaan Aplikasi MyEG}

Terdapat kajian lalu yang membincangkan mengenai penerimaan masyarakat terhadap sesebuah teknologi baharu yang diperkenalkan. Mohd Khairie et al. (2005) mendefinisikan penerimaan sebagai tingkah laku masyarakat untuk menerima atau menolak teknologi baharu. Menurut Maimunah (2000), tingkah laku yang ditonjolkan oleh masyarakat ini sebagai kelakuan untuk mendapatkan sesuatu yang dikehendaki. Penerimaan seseorang terhadap perkara yang diingini ini dipengaruhi oleh tiga ciri iaitu ciri penerima, aspek komunikasi, dan ciri inovasi daripada anggapan penerima. Manakala menurut Gattiker (1984), penerimaan teknologi ditakrifkan sebagai keadaan psikologi individu dengan mengambil kira penggunaan secara sukarela atau bertujuan daripada model penerimaan teknologi tertentu. Penerimaan teknologi ini bertujuan untuk mengkaji bagaimana untuk menggalakkan penggunaan teknologi baharu dan meneroka faktor-faktor yang menghalang atau memudahkan penerimaan sesebuah teknologi (Kripanont, 2007). 
Justeru, beberapa model teknologi telah dibangunkan bagi mengkaji kesan faktorfaktor penerimaan dan penggunaan terhadap teknologi. Model tersebut ialah Theory of Reasoned Action (TRA) (Ajzen \& Fishbein, 1980), Theory of Planned Behaviour (TPB) (Schifter \& Ajzen, 1985), Technology Acceptance Model (TAM) (Davis, 1989), Model of PC Utilization (MPCU) (Thompson, Higgins \& Howell, 1991), Motivational Model (MM) (Davis, Bagozzi \& Warshaw, 1992), Social Cognitive Theory (SCT) (Bandura, 1999), Extension of the Technology Acceptance Model (TAM2) (Venkatesh \& Davis, 2000), Diffusion of Innovation Model (DOI) (Rogers, 2004), dan Unified Theory of Acceptance and Use of Technology (UTAUT) (Venkatesh et al., 2003). Maka untuk pemboleh ubah bersandar kajian ini, penyelidik menggunakan elemen daripada model TAM sebagai panduan kepada pembentukan kerangka kajian ini.

Seterusnya, penyelidik akan membincangkan berkenaan elemen yang menentukan penerimaan aplikasi MyEG kajian ini. Terdapat dua elemen yang digunakan iaitu niat tingkah laku dan tingkah laku penggunaan (Gardner \& Amoroso, 2004). Elemen penerimaan ini dibentuk berasaskan kepada teori Technology Acceptance Model (TAM). Menurut Gardner dan Amoroso (2004), kedua-dua elemen penerimaan ini sesuai digunakan untuk mengkaji penerimaan teknologi baharu seperti Internet.

\section{a. Niat Tingkah Laku}

Niat tingkah laku ditentukan oleh sikap seseorang terhadap penggunaan teknologi. Niat mempengaruhi individu sama ada ingin menggunakan teknologi ataupun sebaliknya. Schaupp et al. (2006) telah menjalankan kajian berkenaan kesan kualiti maklumat dan kepuasan kualiti sistem bagi laman sesawang. Hasil kajian menunjukkan bahawa kualiti maklumat dan sistem kualiti adalah peramal signifikan terhadap kepuasan laman sesawang. Hal ini membuktikan niat pengguna untuk menggunakan laman sesawang adalah ke arah yang positif.

Li dan Jiao (2008) juga mengesahkan terdapat hubungan signifikan antara kualiti laman sesawang dan kepuasan pengguna yang mana hubungan ini memberi kesan kepada penggunaan sebenar perkhidmatan dalam talian. Di samping itu, kajian mengenai persepsi kualiti laman sesawang telah dilaporkan memberi kesan kepada niat tingkah laku (Ahn et al., 2007; Collier \& Bienstock, 2009; Nelson et al., 2005; Parasuraman et al., 2005; Wixom \& Todd, 2005). Maka adalah jelas bahawa kualiti laman sesawang kerajaan yang menyediakan eperkhidmatan adalah faktor penting dalam menentukan niat seseorang. Menurut mereka, jika reka bentuk laman sesawang e-kerajaan adalah satu standard profesional dengan kualiti yang tinggi, maka ia menggalakkan kepuasan pengguna dan memudahkan penerimaan mereka terhadap teknologi tersebut.

Selain itu, beberapa penelitian dari kajian lalu menunjukkan terdapat hubungan yang positif antara sikap dan niat tingkah laku dalam aspek penggunaan teknologi informasi (Malhotra \& Galetta, 1999; Tan \& Teo, 2000; Chau \& Hu, 2002; Lee, 2004; Shih \& Fang, 2004; Gurung, 2006; Hung et al., 2006). Oleh itu, berpandukan sorotan literatur ini, niat penggunaan aplikasi MyEG oleh pengguna adalah penting dalam menentukan penerimaan mereka terhadap aplikasi ini.

\section{b. Tingkah laku Penggunaan Aplikasi MyEG}

Kajian ini juga melihat tingkah laku pengguna terhadap penggunaan aplikasi MyEG. Kajian yang dijalankan oleh Alshehri et al. (2012) berkenaan kesan kualiti laman sesawang terhadap penggunaan perkhidmatan e-kerajaan menjelaskan, tingkah laku penggunaan telah digunakan untuk mengukur penggunaan sebenar bagi perkhidmatan e-kerajaan tersebut. Mereka 
menambah langkah-langkah niat penggunaan amat berguna dalam konteks kajian mereka. Hal ini kerana, hanya warga Arab Saudi yang memerlukan dan perlu menggunakan perkhidmatan e-kerajaan tersebut. Dalam kes ini, langkah penggunaan sebenar boleh membawa kepada kesimpulan yang tepat mengenai penerimaan dan kesesuaian perkhidmatan e-kerajaan.

Seterusnya menurut Thompson et al. (1991), faktor sikap juga adalah sebagai salah satu aspek yang dapat mempengaruhi tingkah laku seseorang pengguna. Mereka menambah, sikap seseorang itu terdiri daripada komponen kognitif, afektif dan komponen yang berkaitan dengan perilaku manusia. Maka, atas faktor ini juga, bagi kajian tingkah laku penggunaan aplikasi MyEG ini turut dipengaruhi oleh sikap pengguna yang menggunakan aplikasi tersebut.

Selain daripada niat tingkah laku yang dapat membentuk perubahan tingkah laku seseorang, niat individu juga bergantung kepada kawalan tingkah laku iaitu sejauh mana efikasi diri dan suasana persekitaran mendorong niat seseorang untuk melaksanakan tingkah laku sebenar. Dua faktor utama yang mendorong pembentukan tingkah laku individu tersebut boleh terdiri daripada faktor langsung dan tidak langsung. Faktor langsung yang dilihat dalam kajian ini terdiri daripada faktor jangkaan prestasi, jangkaan usaha, pengaruh sosial dan suasana dorong. Manakala faktor tidak langsung yang dapat menentukan tingkah laku sebenar seseorang dalam kajian ini adalah niat tingkah laku. Berikut adalah ringkasan perkaitan yang digunakan oleh penyelidik dan diterjemahkan dalam bentuk kerangka konseptual kajian.

Pemboleh ubah Bebas

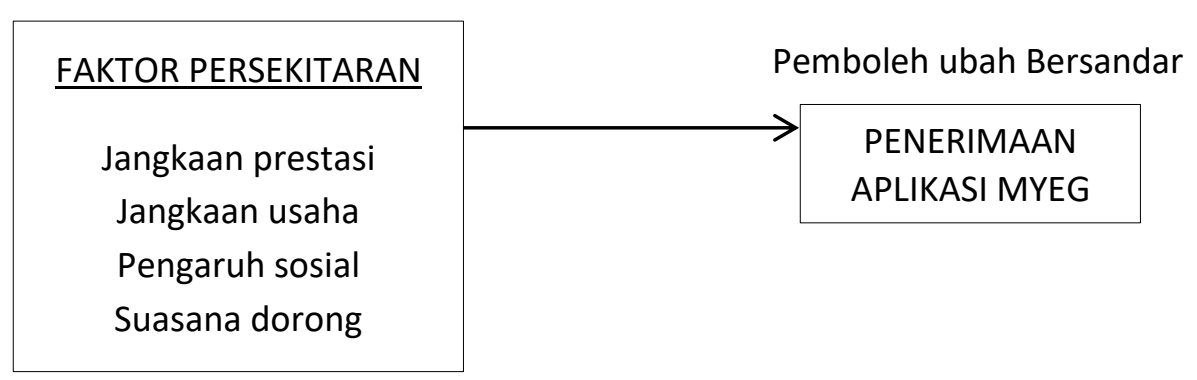

Rajah 1: Kerangka konseptual kajian

\section{METODOLOGI}

Penyelidik menggunakan pendekatan kuantitatif menerusi kaedah tinjauan dengan menggunakan borang soal selidik. Penyelidik menggunakan kaedah kuantitatif kerana keupayaan metod ini dalam membentuk kumpulan kecil manusia bagi melambangkan kumpulan yang lebih besar (Neuman, 2007). Menurut Babbie (2007), kaedah kuantitatif adalah cara terbaik untuk mengumpul data sebenar yang mana ia memerlukan sejumlah besar bilangan orang yang akan diperhatikan secara langsung, berpandukan kepada usaha dan sumber (Dillman, 2000).

Subjek kajian meliputi golongan belia yang sedang atau pernah menggunakan aplikasi MyEG secara dalam talian. Belia dipilih sebagai responden kerana golongan ini merupakan kumpulan umur yang paling ramai menggunakan perkhidmatan dalam talian berbanding golongan umur dewasa (SKMM, 2013). Populasi kajian tertumpu kepada pengguna perkhidmatan aplikasi MyEG yang tinggal di kawasan Lembah Kelang. Manakala sampel kajian pula merujuk kepada proses pemilihan individu daripada populasi (Sulaiman, 2004). Kajian ini menggunakan skala pengukuran sampel Yamane (1967) iaitu seramai 400 orang responden telah dipilih daripada jumlah populasi di Lembah Kelang. Berikut adalah cara pengiraan berdasarkan formula Taro Yamane: 


$$
\begin{aligned}
& n=\frac{N}{1+N(e)^{2}} \\
& n=\frac{632,479}{1+632,479(0.05)^{2}} \\
& n=399.99
\end{aligned}
$$

Kesemua data dianalisis dengan menggunakan perisian SPSS versi 22. Dua prosedur statististik digunakan iaitu statistik deskriptif dan inferensi. Statistik deskriptif digunakan bagi mengenal pasti maklumat berkenaan min, kekerapan, nilai peratusan dan sisihan piawai (May, 2004). Manakala statistik inferensi pula melibatkan kaedah menggunakan maklumat daripada sampel untuk membuat rumusan, ramalan terhadap populasi yang akan menentukan sesuatu keputusan itu boleh diterima (Fathilah \& Zaharul, 2006). Kaedah ini menerusi 'Pearson Product-Moment Correlation' akan menguji perkaitan antara pemboleh ubah bebas dan pemboleh ubah bersandar.

\section{HASIL KAJIAN DAN PERBINCANGAN}

Keseluruhan data profil responden dianalisis secara deskriptif. Berdasarkan Jadual 1, lebih daripada separuh pengguna MyEG adalah lelaki (71.2\%) manakala selebihnya adalah pengguna perempuan $(28.8 \%)$ dengan nilai $\mathrm{N}=396$. Hasil kajian ini berbeza dengan dapatan Ahmad Syahrul Haniff et al. (2011) iaitu penggunaan teknologi baharu seperti e-dagang didominasikan oleh pengguna perempuan. Dari sudut bangsa, Melayu menunjukkan jumlah tertinggi (68.4\%), berbanding Cina (17.2\%) dan India (12.4\%). Turut menjadi responden kajian ini adalah lain-lain bangsa (2.0\%) seperti Iban, Kadazan dan lain-lain kumpulan etnik di Sabah dan Sarawak. Dapatan kajian juga menunjukkan hampir separuh (44.2\%) pengguna MyEG adalah mereka yang bekerja sebagai kakitangan kerajaan. Seterusnya, bagi pendapatan bulanan pengguna MyEG pula menunjukkan majoriti pengguna (96.5\%) adalah berpendapatan dari RM1001 hingga RM4000. Menurut Jabatan Perangkaan Malaysia (2017), kumpulan isi rumah di Malaysia telah dikelaskan kepada tiga kategori iaitu B40, M40 dan T20. Laporan Penyiasatan Perbelanjaan Isi Rumah 2016 menunjukkan bahawa garis pemisah berdasarkan pendapatan telah digunakan untuk menentukan ketiga-tiga golongan ini yang mana golongan B40 adalah isi rumah pendapatan terendah iaitu RM4360 dan ke bawah. Manakala isi rumah kumpulan M40 dan T20 adalah masing-masing berpendapatan RM4361RM9619 dan RM9620 dan ke atas. Maka, dapat dirumuskan bahawa pendapatan bulanan pengguna MyEG berada pada tahap rendah iaitu sebanyak $71 \%$ pengguna berpendapatan antara RM1001 hingga RM4000. 


\begin{tabular}{lrr}
\multicolumn{3}{c}{ Jadual 1: Demografi } \\
\hline Profil & Kekerapan & Peratus \\
\hline Jantina & 282 & 71.2 \\
Lelaki & 114 & 28.8 \\
Perempuan & & \\
Bangsa & 271 & 68.4 \\
Melayu & 68 & 17.2 \\
Cina & 49 & 12.4 \\
India & 8 & 2.0 \\
Lain-lain & & \\
Pekerjaan & 175 & 44.2 \\
Kakitangan kerajaan & 110 & 27.8 \\
Kakitangan swasta & 37 & 9.3 \\
Bekerja sendiri & 74 & 18.7 \\
Lain-lain & & \\
Pendapatan bulanan & 14 & 3.5 \\
RM1000 ke bawah & 88 & 22.2 \\
RM1001-RM2000 & 91 & 23.0 \\
RM2001-RM3000 & 102 & 25.8 \\
RM3001-RM4000 & 101 & 25.5 \\
RM4001 ke atas & & \\
\hline N=396 & &
\end{tabular}

\section{Penerimaan Aplikasi MyEG}

Dapatan seterusnya berkenaan penerimaan pengguna terhadap aplikasi MyEG. Dalam konteks kajian ini, niat tingkah laku merupakan satu bentuk keinginan yang kuat oleh pengguna terhadap penerimaan aplikasi MyEG. Jadual 2 menunjukkan item "Saya bercadang untuk menggunakan aplikasi MyEG pada masa akan datang" adalah item yang memiliki skor min tertinggi iaitu 4.16 dengan $\mathrm{SP}=0.65$. Perkara ini menjelaskan bahawa responden bersetuju untuk menggunakan aplikasi MyEG ini pada masa akan datang kerana aplikasi ini memberi kemudahan kepada mereka. Secara keseluruhannya, elemen niat tingkah laku berada pada tahap yang tinggi dengan skor min keseluruhan 4.04 yang menjelaskan bahawa tahap penerimaan belia terhadap aplikasi MyEG adalah tinggi dan mereka bersetuju untuk meneruskan penggunaan aplikasi ini pada masa hadapan. Hal ini membuktikan bahawa pengguna dapat menerima aplikasi MyEG sebagai aplikasi yang menyediakan kemudahan perkhidmatan kepada mereka.

Jadual 2: Niat Tingkah laku ( $\mathrm{N}=396)$

\begin{tabular}{|c|c|c|c|c|c|c|c|}
\hline \multirow[t]{2}{*}{ Item } & \multicolumn{5}{|c|}{ (\% persetujuan) } & \multirow[t]{2}{*}{ Min } & \multirow[t]{2}{*}{ SP } \\
\hline & 1 & 2 & 3 & 4 & 5 & & \\
\hline $\begin{array}{l}\text { Saya bercadang untuk menggunakan aplikasi MyEG } \\
\text { pada masa akan datang. }\end{array}$ & - & .8 & 11.9 & 57.8 & 29.5 & 4.16 & .65 \\
\hline $\begin{array}{l}\text { Saya berhasrat untuk menggunakan aplikasi MyEG } \\
\text { pada masa hadapan. }\end{array}$ & - & .8 & 11.4 & 60.1 & 27.8 & 4.15 & .63 \\
\hline $\begin{array}{l}\text { Saya percaya bahawa keinginan saya terhadap } \\
\text { aplikasi MyEG pada masa ini akan terus meningkat } \\
\text { pada masa akan datang. }\end{array}$ & - & 4.3 & 11.9 & 54.8 & 29.0 & 4.09 & .76 \\
\hline $\begin{array}{l}\text { Saya akan terus menggunakan aplikasi MyEG dari } \\
\text { semasa ke semasa }\end{array}$ & - & 4.0 & 18.2 & 48.7 & 29.0 & 4.03 & .80 \\
\hline $\begin{array}{l}\text { Saya meramalkan bahawa saya akan menggunakan } \\
\text { aplikasi MyEG pada masa hadapan. }\end{array}$ & - & 2.5 & 33.6 & 43.7 & 20.2 & 3.82 & .78 \\
\hline Min Keseluruhan: 4.04 & & & & & & & \\
\hline
\end{tabular}


Dapatan kajian Burton et al. (2003) mendapati pengalaman positif pengguna adalah saling berkait rapat dengan niat tingkah laku. Semakin banyak pengalaman positif pengguna, maka semakin besar kemungkinan mereka sanggup menggunakan semula perkhidmatan yang ditawarkan. Dapatan Miyamoto et al. (2012) mendapati niat tingkah laku mempengaruhi kepuasan pengguna dengan projek "Enterprise Resources Planning" (ERP) (ERP) di kalangan orang Jepun. Oleh itu, dengan kepuasan seseorang individu terhadap penggunaan teknologi dapat menentukan niat tingkah laku.

Seterusnya adalah hasil dapatan bagi tingkah laku penggunaan aplikasi MyEG. Elemen tingkah laku penggunaan kajian ini menjelaskan berkenaan perlakuan dan tindak balas responden terhadap aplikasi MyEG. Jadual 3 menunjukkan item "Menggunakan aplikasi MyEG adalah idea yang baik" adalah item yang memiliki nilai min tertinggi iaitu 4.15 dan SP=0.70. Hal ini menjelaskan bahawa pengguna bersetuju menyatakan penggunaan aplikasi MyEG dalam kehidupan seharian mereka adalah baik dan bermakna. Oleh itu, secara keseluruhannya elemen tingkah laku pengguna berada pada tahap yang tinggi dengan skor min keseluruhan sebanyak 3.96. Hal ini menunjukkan bahawa tindak balas pengguna terhadap penerimaan aplikasi MyEG adalah tinggi dan mereka bersetuju untuk menggunakan aplikasi ini dari semasa ke semasa kerana ia adalah sebuah idea yang baik.

Jadual 3: Tingkah laku Penggunaan Terhadap Penerimaan Aplikasi MyEG (N=396)

\begin{tabular}{|c|c|c|c|c|c|c|c|}
\hline \multirow[t]{2}{*}{ Item } & \multicolumn{5}{|c|}{ (\% persetujuan) } & \multirow[t]{2}{*}{ Min } & \multirow[t]{2}{*}{ SP } \\
\hline & 1 & 2 & 3 & 4 & 5 & & \\
\hline $\begin{array}{l}\text { Saya menggunakan perkhidmatan aplikasi MyEG } \\
\text { setelah mengetahui kelebihannya. }\end{array}$ & - & .8 & 15.7 & 51.8 & 31.8 & 4.15 & .70 \\
\hline $\begin{array}{l}\text { Saya menggunakan perkhidmatan aplikasi MyEG } \\
\text { tanpa berasa takut. }\end{array}$ & - & 2.0 & 18.2 & 46.0 & 33.8 & 4.12 & .77 \\
\hline $\begin{array}{l}\text { Saya terus menggunakan perkhidmatan aplikasi } \\
\text { MyEG dari semasa ke semasa. }\end{array}$ & - & 3.5 & 20.7 & 49.2 & 26.5 & 3.99 & .78 \\
\hline $\begin{array}{l}\text { Saya menggalakkan orang lain (keluarga/rakan- } \\
\text { rakan) untuk menggunakan kemudahan aplikasi } \\
\text { MyEG. }\end{array}$ & .5 & 2.5 & 24.7 & 45.2 & 27.0 & 3.96 & .81 \\
\hline $\begin{array}{l}\text { Saya meningkatkan kemahiran mengendalikan } \\
\text { kemudahan aplikasi MyEG setelah mengetahui } \\
\text { kegunaannya }\end{array}$ & .5 & 8.1 & 33.3 & 45.2 & 12.9 & 3.62 & .83 \\
\hline Min Keseluruhan: 3.96 & & & & & & & \\
\hline
\end{tabular}

Dapatan kajian ini menyokong hasil kajian Hong et al. (2006) iaitu tingkah laku penggunaan adalah sangat penting khususnya bagi pengguna Internet mudah alih. Hasil kajian penyelidik ini membuktikan bahawa kecenderungan yang positif akan menggalakkan pengguna untuk terus menggunakan Internet mudah alih. Kajian hampir sama dijalankan Shahril et al. (2012) berkenaan penggunaan komputer dan Internet di sekolah. Hasil kajian mendapati guru tidak akan mengelakkan diri daripada menggunakan komputer dan mereka akan terus mengajar subjek yang diberikan sekiranya mereka perlu menggunakan komputer dalam proses pengajaran dan pembelajaran. Hal ini menunjukkan guru-guru bersikap positif dan akan terus menggunakan komputer dalam proses pengajaran mereka. Oleh itu, selaras dengan kajian lalu ini membuktikan bahawa sikap positif pengguna aplikasi MyEG akan menyebabkan mereka terus menggunakan aplikasi ini di masa akan datang. 


\section{Faktor Peramal Bagi Penerimaan Aplikasi MyEG}

Faktor peramal pertama yang dibincangkan adalah pengaruh sosial. Dalam konteks kajian ini, pengaruh sosial adalah pengaruh daripada orang sekeliling terutamanya ahli keluarga, saudara mara, teman-teman dan juga pihak media agar individu itu menggunakan aplikasi MyEG.

Jadual 4 menunjukkan item pengaruh sosial yang memperoleh skor min tertinggi adalah "Iklan MyEG di televisyen, radio, dan akhbar akan mempengaruhi saya untuk menggunakan aplikasi MyEG" dengan min 3.41 dan $\mathrm{SP}=1.19$. Hal ini menjelaskan responden bersetuju elemen seperti media massa boleh mempengaruhi mereka untuk menggunakan aplikasi MyEG. Manakala bagi item yang memiliki skor min paling rendah untuk elemen pengaruh sosial adalah "Saya akan menggunakan aplikasi MyEG sekiranya teman-teman saya menggunakannya" dengan min 2.60 dan SP=1.21. Keadaan ini menerangkan pengguna tidak bersetuju apabila menyatakan teman-teman mereka adalah faktor yang mempengaruhi mereka untuk menggunakan aplikasi MyEG.

Oleh itu, secara keseluruhannya elemen pengaruh sosial berada pada tahap sederhana dengan skor min keseluruhan sebanyak 3.08. Hal ini menunjukkan pengguna merasakan melalui hebahan iklan daripada sumber media massa dan kehadiran orang sekeliling seperti masyarakat setempat mahupun rakan sekerja, adalah salah satu faktor yang mendorong mereka untuk menggunakan aplikasi MyEG.

Kajian Sumak et al. (2010) menyatakan pengaruh sosial mempunyai kesan besar kepada penggunaan inovasi elektronik baharu. Hasil kajian membuktikan saluran teknologi komunikasi seperti televisyen adalah salah satu medium yang masih relevan dan luas kesan penggunaannya. Justeru, hasil daripada kajian ini mendapati kesan daripada iklan di media tradisional seperti iklan MyEG telah memberikan input kepada masyarakat untuk mengetahui dengan lebih lanjut maklumat perkhidmatan tersebut. Manakala hasil kajian Ismail dan Ali Yassin (2014) pula mendapati pengaruh sosial memberi kesan tidak langsung terhadap kepuasan melalui niat. Ini bermakna bahawa niat pelajar untuk menggunakan teknologi $3 G$ dipengaruhi oleh rakan-rakan, ahli keluarga, pensyarah, dan persekitaran sosial yang lain.

Jadual 4: Pengaruh Sosial ( $N=396)$

\begin{tabular}{|c|c|c|c|c|c|c|c|}
\hline \multirow[t]{2}{*}{ Item } & \multicolumn{5}{|c|}{ (\% persetujuan) } & \multirow[t]{2}{*}{ Min } & \multirow[t]{2}{*}{ SP } \\
\hline & 1 & 2 & 3 & 4 & 5 & & \\
\hline $\begin{array}{l}\text { Iklan MyEG di televisyen, radio, dan akhbar } \\
\text { akan mempengaruhi saya untuk } \\
\text { menggunakan aplikasi MyEG. }\end{array}$ & 9.1 & 11.6 & 27.3 & 32.8 & 19.2 & 3.41 & 1.19 \\
\hline $\begin{array}{l}\text { Saya akan menggunakan aplikasi MyEG jika ia } \\
\text { digunakan oleh masyarakat. }\end{array}$ & 5.8 & 18.4 & 24.0 & 40.2 & 11.6 & 3.33 & 1.08 \\
\hline $\begin{array}{l}\text { Saya menggunakan aplikasi MyEG disebabkan } \\
\text { oleh perkongsian daripada rakan sekerja } \\
\text { yang menggunakan aplikasi tersebut. }\end{array}$ & 14.6 & 18.4 & 13.6 & 41.2 & 12.1 & 3.18 & 1.28 \\
\hline $\begin{array}{l}\text { Umumnya, saya banyak dipengaruhi orang lain } \\
\text { untuk menggunakan aplikasi MyEG. }\end{array}$ & 11.6 & 13.1 & 34.6 & 30.6 & 10.1 & 3.14 & 1.13 \\
\hline $\begin{array}{l}\text { Saranan daripada teman-teman akan } \\
\text { mempengaruhi keputusan saya untuk } \\
\text { menggunakan aplikasi MyEG. }\end{array}$ & 16.2 & 17.4 & 21.7 & 3.61 & 8.6 & 3.04 & 1.24 \\
\hline $\begin{array}{l}\text { Ahli keluarga/ saudara mara saya akan } \\
\text { mempengaruhi keputusan saya untuk } \\
\text { menggunakan aplikasi MyEG. }\end{array}$ & 12.1 & 21.7 & 30.8 & 25.0 & 10.4 & 3.00 & 1.17 \\
\hline $\begin{array}{l}\text { Teman sekeliling sangat membantu saya untuk } \\
\text { menggunakan aplikasi MyEG dalam } \\
\text { pekerjaan harian saya. }\end{array}$ & 17.2 & 19.7 & 19.2 & 36.6 & 7.3 & 2.97 & 1.24 \\
\hline
\end{tabular}




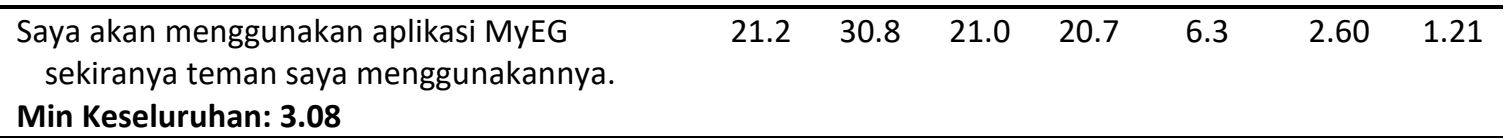

Di samping itu, menurut kebiasaan masyarakat di Malaysia, penggunaan sesebuah aplikasi turut dipengaruhi oleh penggunaan masyarakat dalam negara mahupun luar negara. Ini disokong dalam kajian Siti Zobidah et al. (2008) yang menjelaskan masyarakat di Malaysia amat sukar menerima terus sesebuah teknologi baharu tanpa adanya bukti atau perkembangan positif dari negara luar tentang kejayaan teknologi baharu yang diperkenalkan. Oleh itu, apabila masyarakat ramai menggunakan aplikasi MyEG, maka ia memberi keyakinan kepada pengguna untuk menggunakannya. Menurut Ajzen (1991), pengaruh sosial adalah faktor signifikan kepada seseorang untuk mempengaruhi mereka menggunakan sesebuah teknologi baharu.

Namun begitu, terdapat perbezaan dapatan Raidah et al. (2013) yang menyatakan pengaruh rakan-rakan adalah faktor utama dalam penggunaan ICT oleh masyarakat nelayan. Begitu juga kajian Fan et al. (2005) yang turut melaporkan cadangan dari teman-teman adalah faktor signifikan dalam penghebahan sesuatu maklumat. Dilaporkan bahawa pengguna lebih gemar memberi cadangan berkaitan sesuatu perkhidmatan sekiranya mereka berpuas hati dengan perkhidmatan yang disediakan. Mereka kebiasaannya akan memberitahu kepada rakan terdekat supaya mencuba sistem yang diperkenalkan tersebut (Fan et al., 2005).

Seterusnya adalah hasil kajian mengenai jangkaan prestasi. Bagi kajian ini jangkaan prestasi merujuk kepada kehadiran aplikasi MyEG dapat membantu pengguna mengoptimumkan prestasi kerja mereka dengan lebih baik. Jadual 5 menunjukkan item "Dengan menggunakan aplikasi MyEG, ianya banyak menjimatkan masa saya" merupakan item yang memiliki skor min tertinggi ( $M i n=4.12$; $S P=0.75$ ) iaitu sebanyak $49.2 \%$ responden setuju aplikasi MyEG ini dapat menjimatkan masa mereka apabila menggunakannya. Begitu juga dengan item "Dengan menggunakan aplikasi MyEG, ianya membolehkan saya menyempurnakan kerja harian dengan lebih cepat" berada pada kedudukan min kedua tertinggi $=4.02$ dengan $\mathrm{SP}=0.78$. Keadaan ini menunjukkan responden setuju bahawa aplikasi MyEG membantu mereka menyelesaikan tugasan harian dengan lebih pantas dan tidak perlu mengambil masa yang banyak.

Oleh itu, secara keseluruhannya elemen jangkaan prestasi berada pada tahap yang tinggi dengan skor min keseluruhan 3.83. Situasi ini menerangkan jangkaan prestasi adalah merupakan salah satu elemen yang dapat membantu pengguna mengoptimumkan prestasi kerja mereka ke tahap yang lebih baik kerana pada pandangan responden tersebut, untuk menghasilkan kualiti kerja yang sempurna aspek penjagaan masa adalah amat dititik beratkan. Keadaan ini bersesuaian dengan kehadiran aplikasi MyEG yang mana membantu pengguna menyempurnakan kerja dengan lebih mudah dan cepat. 


\begin{tabular}{|c|c|c|c|c|c|c|c|}
\hline \multicolumn{8}{|c|}{ Jadual 5: Jangkaan Prestasi (N=396) } \\
\hline \multirow[t]{2}{*}{ Item } & \multicolumn{5}{|c|}{ (\% persetujuan) } & \multirow[t]{2}{*}{ Min } & \multirow[t]{2}{*}{ SP } \\
\hline & 1 & 2 & 3 & 4 & 5 & & \\
\hline $\begin{array}{l}\text { Dengan menggunakan aplikasi MyEG, ianya } \\
\text { banyak menjimatkan masa saya. }\end{array}$ & - & 2.0 & 16.4 & 49.2 & 32.3 & 4.12 & .75 \\
\hline $\begin{array}{l}\text { Dengan menggunakan aplikasi MyEG, ianya } \\
\text { membolehkan saya menyempurnakan kerja } \\
\text { harian dengan lebih cepat. }\end{array}$ & - & 3.5 & 18.4 & 50.3 & 27.8 & 4.02 & .78 \\
\hline $\begin{array}{l}\text { Dengan menggunakan aplikasi MyEG, ianya } \\
\text { dapat menjadikan pekerjaan harian saya lebih } \\
\text { senang untuk dilakukan. }\end{array}$ & 2.0 & 2.8 & 25.3 & 47.2 & 22.7 & 3.86 & .87 \\
\hline $\begin{array}{l}\text { Saya mendapati aplikasi MyEG sangat berguna } \\
\text { dalam kehidupan saya. }\end{array}$ & 5 & 3.3 & 27.3 & 53.0 & 15.9 & 3.81 & .76 \\
\hline $\begin{array}{l}\text { Secara umumnya, saya mempercayai aplikasi } \\
\text { MyEG dapat membantu meningkatkan prestasi } \\
\text { kerja saya. }\end{array}$ & 1.5 & 2.3 & 36.6 & 42.2 & 17.4 & 3.71 & .83 \\
\hline $\begin{array}{l}\text { Dengan menggunakan aplikasi MyEG, ia dapat } \\
\text { meningkatkan produktiviti kerja harian saya. }\end{array}$ & 2.0 & 6.6 & 30.6 & 43.4 & 17.4 & 3.68 & .91 \\
\hline $\begin{array}{l}\text { Dengan menggunakan aplikasi MyEG, ianya } \\
\text { dapat menambahbaikkan kecekapan dalam } \\
\text { pekerjaan harian saya. }\end{array}$ & 1.5 & 5.3 & 34.1 & 45.7 & 13.4 & 3.64 & .83 \\
\hline Min Keseluruhan: $\mathbf{3 . 8 3}$ & & & & & & & \\
\hline
\end{tabular}

Dapatan kajian ini menyokong hasil kajian Al-Shafi dan Weerakkody (2010) iaitu jangkaan prestasi dapat diukur dengan melihat persepsi masyarakat menggunakan perkhidmatan e-kerajaan. Hasil kajian mendapati penggunaan aplikasi e-kerajaan dapat memberi manfaat kepada rakyat seperti menjimatkan masa, wang dan usaha. Di samping itu, penggunaan aplikasi tersebut dapat memudahkan komunikasi mereka dengan pihak kerajaan serta meningkatkan kualiti perkhidmatan kerajaan. Selaras dengan kajian lalu, dengan manfaat yang diperolehi oleh pengguna aplikasi MyEG ini keinginan mereka untuk menggunakan aplikasi MyEG dari semasa ke semasa akan terus meningkat.

Dari segi jangkaan usaha pula, kajian ini memberi tumpuan dari aspek usaha yang ditonjolkan oleh pengguna ketika melayari aplikasi MyEG. Berdasarkan Jadual 6, nilai min tertinggi adalah "Interaksi saya dengan aplikasi MyEG mudah difahami" (Min=3.99; SP=0.70). Diikuti item "Interaksi saya dengan aplikasi MyEG adalah jelas" dengan min 3.97; SP=0.72. Manakala nilai min ketiga tertinggi adalah "Secara keseluruhannya, saya percaya bahawa aplikasi MyEG mudah untuk digunakan" (Min=3.85; SP=0.72). Kesemua keadaan ini menjelaskan responden setuju bahawa aplikasi MyEG adalah aplikasi yang mudah untuk digunakan dan mereka faham setiap arahan yang diberikan ketika menggunakan aplikasi tersebut. Hal ini menunjukkan masyarakat hari ini celik teknologi maklumat dan menggunakan aplikasi MyEG ini bukanlah satu kesukaran bagi mereka untuk memahaminya.

Oleh itu, secara keseluruhan untuk elemen jangkaan usaha berada pada tahap yang tinggi dengan min keseluruhan 3.81. Ini menunjukkan bahawa aplikasi MyEG adalah aplikasi yang mudah untuk diuruskan dan digunakan oleh pengguna tersebut. Hal ini kerana setiap interaksi antara pengguna dan aplikasi MyEG adalah difahami, jelas dan berbentuk fleksibel terutamanya ketika berurusan. 


\begin{tabular}{|c|c|c|c|c|c|c|c|}
\hline \multicolumn{8}{|c|}{ Jadual 6: Jangkaan Usaha ( $\mathrm{N}=396)$} \\
\hline \multirow[t]{2}{*}{ Item } & \multicolumn{5}{|c|}{ (\% persetujuan) } & \multirow[t]{2}{*}{ Min } & \multirow[t]{2}{*}{ SP } \\
\hline & 1 & 2 & 3 & 4 & 5 & & \\
\hline $\begin{array}{l}\text { Interaksi saya dengan aplikasi MyEG mudah } \\
\text { difahami. }\end{array}$ & - & 2.8 & 16.7 & 59.3 & 21.2 & 3.99 & .70 \\
\hline Interaksi saya dengan aplikasi MyEG adalah jelas. & - & 3.5 & 17.4 & 58.3 & 20.7 & 3.97 & .72 \\
\hline $\begin{array}{l}\text { Secara keseluruhannya, saya percaya bahawa } \\
\text { aplikasi MyEG mudah untuk digunakan. }\end{array}$ & - & 2.8 & 26.3 & 54.3 & 16.7 & 3.85 & .72 \\
\hline $\begin{array}{l}\text { Belajar menggunakan aplikasi MyEG adalah } \\
\text { mudah bagi saya. }\end{array}$ & - & 2.8 & 31.1 & 48.0 & 18.2 & 3.82 & .76 \\
\hline $\begin{array}{l}\text { Saya mendapati aplikasi MyEG mudah untuk } \\
\text { digunakan seperti yang saya mahukan. }\end{array}$ & - & 3.3 & 24.7 & 61.4 & 10.6 & 3.79 & .67 \\
\hline $\begin{array}{l}\text { lanya mudah bagi saya untuk menjadi cekap } \\
\text { dalam menggunakan aplikasi MyEG. }\end{array}$ & - & 3.8 & 29.5 & 50.8 & 15.9 & 3.79 & .75 \\
\hline $\begin{array}{l}\text { Saya mendapati aplikasi MyEG fleksibel dalam } \\
\text { berinteraksi. }\end{array}$ & .5 & 5.8 & 30.3 & 50.8 & 12.6 & 3.69 & .78 \\
\hline $\begin{array}{l}\text { Saya berusaha mempelajari menggunakan aplikasi } \\
\text { MyEG. }\end{array}$ & 1.8 & 6.1 & 31.3 & 50.0 & 10.9 & 3.62 & .83 \\
\hline Min Keseluruhan: $\mathbf{3 . 8 1}$ & & & & & & & \\
\hline
\end{tabular}

Menurut Venkatesh et al. (2003), faktor jangkaan usaha adalah tahap kemudahan bagi sesebuah sistem. Ismail dan Ali Yassin (2014) menjelaskan elemen jangkaan usaha memberi kesan positif dan signifikan terhadap penggunaan teknologi mobil 3G. Begitu juga dengan pendapat Kijsanayotin et al. (2009) yang menyatakan konstruk jangkaan usaha dapat memberi kemudahan terutamanya kepada pengguna e-kerajaan.

Elemen terakhir yang digunakan ialah suasana dorong. Dalam kajian ini, suasana dorong menerangkan situasi dialami oleh pengguna ketika menggunakan aplikasi MyEG. Jadual 7 mendapati min tertinggi ( $M i n=4.32 ; S P=0.76$ ) adalah "Saya mempunyai kemudahan yang diperlukan seperti kemudahan internet ketika menggunakan aplikasi MyEG". Hal ini menunjukkan responden sangat setuju menyatakan mereka memiliki kemudahan internet sebelum melayari aplikasi MyEG. Ini kerana kesemua responden tersebut tinggal di kawasan Lembah Kelang dan kawasan tersebut mempunyai penembusan internet yang mudah dan laju. Dengan kehadiran internet, pengguna tidak berasa sukar untuk menggunakan aplikasi ini.

Seterusnya, item yang memiliki min kedua tertinggi ialah "Aplikasi MyEG adalah tidak sama dengan sistem lain yang pernah saya gunakan seperti microsoft word dan excel" (Min=4.26; SP=0.73). Keadaan ini menjelaskan responden sangat setuju penyataan yang diberikan dengan peratusan sebanyak 42.7\%. Dapatan kajian menunjukkan responden faham akan perbezaan aplikasi MyEG dengan sistem lain yang pernah mereka gunakan.

Oleh itu, secara keseluruhannya elemen suasana dorong juga berada pada tahap yang tinggi dengan skor min keseluruhan 3.87. Ini menjelaskan bahawa suasana dorong turut memainkan peranan penting dalam menggalakkan orang ramai untuk menggunakan aplikasi MyEG. Dengan kehadiran internet pada telefon mudah alih mereka mahupun WIFI yang disediakan ditempat kerja maka dapat membantu pengguna untuk melayari aplikasi MyEG ini dengan mudah. 


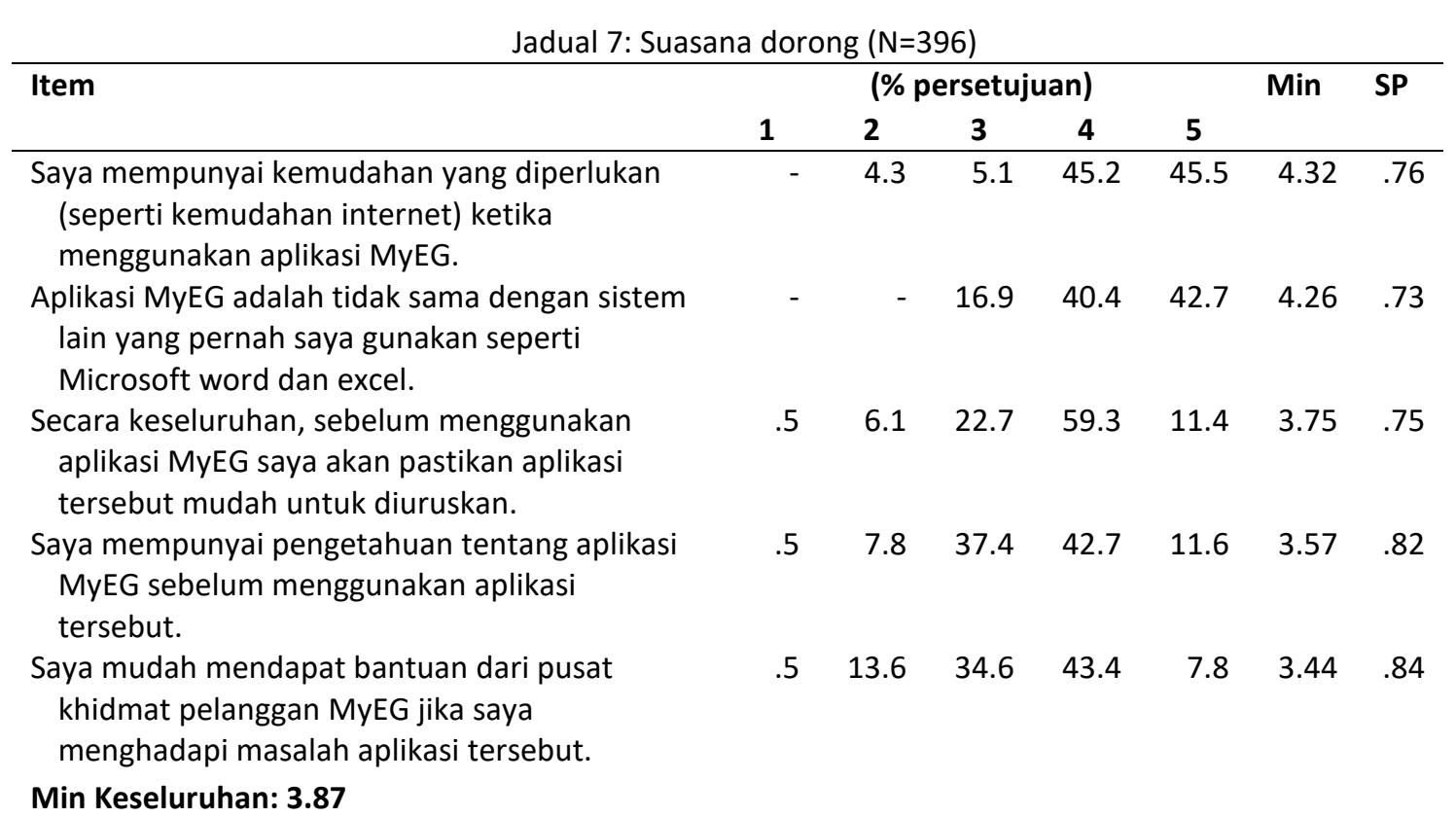

Dapatan kajian ini selaras dengan Norashikin et al. (2011) yang menyenaraikan kemudahan pusat capaian Internet awam seperti kampung Wi-Fi dan Pusat Internet Desa sebagai kemudahan yang diperlukan oleh orang awam dalam menggunakan aplikasi ekerajaan. Mereka turut menambah orang awam berasa lebih mudah, selesa dan tidak tertekan apabila ingin menggunakan aplikasi yang disediakan oleh pihak kerajaan kepada mereka.

\section{Perkaitan Faktor Peramal Dengan Penerimaan Aplikasi MyEG}

Ditinjau aspek perkaitan setiap elemen faktor peramal (jangkaan prestasi, jangkaan usaha, pengaruh sosial dan suasana dorong) yang digunakan oleh pengguna kajian ini, semua elemen tersebut berkait secara positif dengan tahap penerimaan aplikasi MyEG. Jadual 8 menunjukkan untuk elemen jangkaan prestasi, ia mempunyai perkaitan positif yang kuat $(r=0.728, p=0.000)$ dengan penerimaan aplikasi MyEG. Ini bermakna semakin pengguna aplikasi MyEG bersetuju menyatakan elemen tersebut mempengaruhi mereka maka semakin meningkat tahap penerimaan mereka terhadap aplikasi ini. Hasil kajian ini selari dengan Marchewka et al. (2007) iaitu melalui jangkaan prestasi, ia dapat menentukan penerimaan pengguna terhadap teknologi maklumat.

Selain dari elemen jangkaan prestasi, kajian menunjukkan elemen jangkaan usaha perlu diambil perhatian dalam menggalakkan orang ramai untuk terus menggunakan aplikasi tersebut. Jangkaan usaha mempunyai kaitan positif yang sederhana ( $r=0.651, p=0.000)$ dengan tahap penerimaan aplikasi MyEG. Apabila elemen jangkaan usaha semakin dipersetujui oleh pengguna maka semakin meningkat tahap penerimaan mereka terhadap aplikasi MyEG. Kajian ini menyokong dapatan Carlsson (2006) iaitu jangkaan usaha adalah faktor penentu bagi penggunaan sebenar perkhidmatan dalam talian oleh golongan belia.

Faktor suasana dorong juga merupakan faktor yang berkaitan secara sederhana dan positif ( $r=0.611, p=0.000$ ) dengan penerimaan aplikasi MyEG. Ini dapat disimpulkan, semakin bersetuju pengguna terhadap faktor suasana dorong maka semakin tinggi tahap penerimaan mereka terhadap aplikasi MyEG. Faktor suasana dorong adalah salah satu faktor penting dalam menilai pandangan masyarakat terhadap penerimaan mereka menggunakan aplikasi MyEG. Ini kerana apabila suasana dorong ini wujud seperti dengan kehadiran internet, pengguna akan berasa tidak sukar untuk melayari aplikasi MyEG ini. Hasil kajian ini menyamai 
dapatan (Cheung \& Chang, 2000; Jones et al., 2002) yang menyatakan faktor suasana dorong mempunyai kesan yang positif ke atas penggunaan beberapa inovasi baharu di dalam sistem maklumat.

Seterusnya bagi faktor pengaruh sosial pula, kajian ini mendapati terdapat perkaitan positif yang lemah $(r=0.465, p=0.000)$ antara pengaruh sosial dengan penerimaan aplikasi MyEG. Walaupun perkaitan ini lemah tetapi perkaitan ini signifikan. Oleh itu, semakin tinggi faktor pengaruh sosial dipersetujui, maka tahap penerimaan bagi aplikasi MyEG berpotensi untuk meningkat walaupun pada kadar yang rendah. Perkaitan positif yang lemah ini dapat dikaitkan dengan pengaruh orang-orang terdekat seperti ahli keluarga dan rakan-rakan untuk membantu pengguna menggunakan aplikasi MyEG. Ini kerana lazimnya pengguna aplikasi MyEG tidak akan menggunakan aplikasi ini jika tiada orang lain atau sumber lain seperti televisyen, radio atau surat khabar menggunakan aplikasi ini terlebih dahulu.

Walau bagaimanapun, terdapat perbezaan dengan hasil dapatan Yu (2012) berkenaan perbankan mudah alih di Taiwan. Beliau mendapati terdapat perkaitan yang kuat antara pengaruh sosial dalam mempengaruhi niat seseorang untuk menggunakan perbankan mudah alih berbanding faktor yang lain. Dapatan Sripalawat et al. (2011) berkenaan M-banking di kota metropolitan Bangkok turut mendapati faktor pengaruh sosial sangat mempengaruhi niat pengguna untuk menggunakan perkhidmatan dalam talian.

Jadual 8: Ujian Korelasi antara Pengaruh Sosial, Jangkaan Prestasi, Jangkaan Usaha dan Suasana dorong dengan Penerimaan Aplikasi MyEG (N=396)

\begin{tabular}{lcc}
\hline & \multicolumn{2}{c}{ Penerimaan Aplikasi MyEG } \\
Pembolehubah & $\mathbf{r}$ & Nilai Signifikan \\
\hline Jangkaan prestasi & .728 & .000 \\
Jangkaan usaha & .651 & .000 \\
Suasana dorong & .611 & .000 \\
Pengaruh sosial & .465 & .000 \\
\hline
\end{tabular}

\section{Faktor Yang Menyumbang Penerimaan Aplikasi MyEG}

Bagi menentukan faktor peramal yang menyumbang penerimaan aplikasi MyEG, analisis multi regresi telah digunakan. Melalui analisis tersebut, didapati faktor jangkaan prestasi, suasana dorong, pengaruh sosial dan jangkaan usaha merupakan pemboleh ubah peramal kepada penerimaan aplikasi MyEG. Dapatan kajian menunjukkan keempat-empat faktor tersebut merupakan pemboleh ubah peramal yang mempengaruhi penerimaan aplikasi MyEG.

Melalui ujian Anova untuk analisis regresi menunjukkan terdapat hubungan yang signifikan di antara pemboleh ubah bersandar dengan pemboleh ubah bebas iaitu pada aras signifikan 0.05. Analisis (Jadual 9) mendapati jangkaan prestasi (Model 1) memberikan hasil yang signifikan $\mathrm{F}=423.813, \mathrm{p}<0.05$. Begitu juga gabungan jangkaan prestasi dan suasana dorong (Model 2) turut memberikan hasil signifikan ( $F=256.147, p<0.05)$. Selanjutnya, bagi gabungan jangkaan prestasi, suasana dorong dan pengaruh sosial (Model 3) menunjukkan hasil yang signifikan $(F=192.407, p<0.05)$ dan akhir sekali gabungan keempat-empat pemboleh ubah iaitu jangkaan prestasi, suasana dorong, pengaruh sosial dan jangkaan usaha (Model 4) turut memberikan nilai hasil yang signifikan $F=152.838, p<0.05$. 


\begin{tabular}{|c|c|c|c|c|c|c|}
\hline & Model & Sum of Squares & df & $\begin{array}{l}\text { Mean } \\
\text { Square }\end{array}$ & $\mathbf{F}$ & $\begin{array}{c}\text { Sig. } \\
\text { Value }\end{array}$ \\
\hline \multirow[t]{3}{*}{1.} & Regression & 9422.922 & 1 & 9422.922 & 423.813 & 0.000 \\
\hline & Residual & 8760.078 & 394 & 22.234 & & \\
\hline & Total & 18183.000 & 395 & & & \\
\hline \multirow[t]{3}{*}{2.} & Regression & 10289.513 & 2 & 5144.756 & 256.147 & 0.000 \\
\hline & Residual & 7893.487 & 393 & 20.085 & & \\
\hline & Total & 18183.000 & 395 & & & \\
\hline \multirow[t]{3}{*}{3.} & Regression & 10828.909 & 3 & 3609.636 & 192.407 & 0.000 \\
\hline & Residual & 7354.091 & 392 & 18.760 & & \\
\hline & Total & 18183.000 & 395 & & & \\
\hline & Regression & 11090.125 & 4 & 2772.531 & 152.838 & 0.000 \\
\hline & Residual & 7092.875 & 391 & 18.140 & & \\
\hline & Total & 18183.000 & 395 & & & \\
\hline
\end{tabular}

Sementara itu, ujian multi regresi (Jadual 10) menunjukkan jangkaan prestasi adalah pemberi nilai sumbangan signifikan tertinggi iaitu $51.8 \%$ varians $\left(R^{2}=0.518\right)$ terhadap penerimaan aplikasi MyEG. Hal ini menjelaskan faktor jangkaan prestasi $(\beta=0.72, p<0.05)$ ialah penyumbang utama yang menyebabkan responden menerima aplikasi MyEG. Walau bagaimanapun, dengan kombinasi dua peramal iaitu jangkaan prestasi $(\beta=0.56, p<0.05)$ dan suasana dorong $(\beta=0.27, p<0.05)$ nilai sumbangan varians terhadap penerimaan aplikasi MyEG meningkat kepada 56.6\%. Jumlah peningkatan ini adalah sebanyak 4.8\% (56.6-51.8=4.8\%). Keadaan ini menunjukkan kedua-dua faktor tersebut digabungkan turut menyumbang kepada penerimaan belia terhadap aplikasi MyEG.

Seterusnya, apabila jangkaan prestasi $(\beta=0.44, p<0.05)$ digabungkan dengan suasana dorong $(\beta=0.31, p<0.05)$ dan pengaruh sosial $(\beta=0.20, p<0.05)$ didapati jumlah peratusan meningkat sebanyak $59.6 \%$ dengan penambahan sebanyak 3\% (59.6-56.6=3\%). Ini bermaksud sikap belia terhadap aplikasi MyEG sama ada menerima atau menolak turut dipengaruhi oleh faktor pengaruh sosial.

Akhirnya, analisis juga mendapati apabila jangkaan prestasi $(\beta=0.34, p<0.05)$ digabungkan dengan suasana dorong $(\beta=0.26, p<0.05)$, pengaruh sosial $(\beta=0.20, p<0.05)$ dan jangkaan usaha $(\beta=0.18, p<0.05)$ nilai sumbangan varians terhadap penerimaan aplikasi MyEG turut meningkat sebanyak 61\%. Jumlah peningkatan ini adalah sebanyak $1.4 \%$ (61.0$59.6=1.4 \%)$. Oleh itu, hasil kajian menunjukkan faktor jangkaan usaha juga menyumbang kepada penerimaan aplikasi MyEG.

Jadual 10: Regresi Pekali Pemboleh Ubah Bebas: Analisis Multi Regresi, Kaedah Stepwise

\begin{tabular}{lcccc}
\hline Model & $\boldsymbol{\beta}$ & Beta & $\mathbf{t}$ & Sig. Value \\
& & & & \\
\hline 1 (constant) & 39.459 & & 30.662 & 0.000 \\
Jangkaan prestasi & 0.970 & 0.720 & 20.587 & 0.000 \\
2 (constant) & 31.902 & & 18.998 & 0.000 \\
Jangkaan prestasi & 0.755 & 0.560 & 13.607 & 0.000 \\
Suasana dorong & 0.689 & 0.270 & 6.569 & 0.000 \\
3 (constant) & 29.259 & & 17.251 & 0.000 \\
Jangkaan prestasi & 0.595 & 0.441 & 9.682 & 0.000 \\
Suasana dorong & 0.779 & 0.305 & 7.575 & 0.000 \\
Pengaruh social & 0.212 & 0.200 & 5.362 & 0.000 \\
& & & & \\
\hline
\end{tabular}




\begin{tabular}{lcrrr}
\hline 4 (constant) & 27.278 & & 15.608 & 0.000 \\
Jangkaan prestasi & 0.459 & 0.341 & 6.542 & 0.000 \\
Suasana dorong & 0.666 & 0.261 & 6.316 & 0.000 \\
Pengaruh sosial & 0.214 & 0.202 & 5.509 & 0.000 \\
Jangkaan usaha & 0.254 & 0.177 & 3.795 & 0.000 \\
& $\mathbf{R}$ & $\mathbf{R}^{\mathbf{2}}$ & Adjusted R & \\
& 0.720 & 0.518 & 0.517 & \\
1 & 0.752 & 0.566 & 0.564 & \\
3 & 0.772 & 0.596 & 0.592 & \\
4 & 0.781 & 0.610 & 0.606 & \\
\hline
\end{tabular}

Berdasarkan keputusan analisis multi regresi dari Jadual 9 dan 10, secara keseluruhannya keempat-empat faktor peramal tersebut telah menyumbang sebanyak $61 \%$ $\left(R^{2}=0.610\right)$ kepada perubahan penerimaan belia terhadap aplikasi MyEG. Sebagai kesimpulannya, ujian analisis multi regresi menunjukkan sikap belia untuk menerima aplikasi MyEG dipengaruhi oleh kesemua faktor yang telah diuji. Dapatan ini juga membuktikan bahawa faktor jangkaan prestasi adalah faktor penyumbang tertinggi dan diikuti oleh faktor suasana dorong, pengaruh sosial dan jangkaan usaha dalam mempengaruhi belia untuk menerima ataupun menolak aplikasi MyEG ini.

\section{KESIMPULAN}

Oleh kerana kajian ini melibatkan beberapa pihak seperti kerajaan, rakyat dan golongan perniagaan, kajian ini dapat membantu mereka mengenali pemasalahan yang timbul berkenaan dengan aplikasi MyEG. Bagi pihak kerajaan, dapat membantu dari aspek penilaian masyarakat terhadap aplikasi MyEG. Pihak kerajaan secara tidak langsung mengenal pasti masalah yang terjadi mengenai kurang sambutannya aplikasi MyEG ini. Oleh itu, adalah disarankan agar pihak kerajaan mengambil langkah yang sewajarnya untuk meningkatkan penggunaan aplikasi MyEG secara dalam talian ini.

Kewujudan aplikasi MyEG sebagai kemudahan buat masyarakat adalah amat baik kerana ia memudahkan mereka untuk berurusan dengan pihak kerajaan. Kesedaran masyarakat terhadap kemudahan aplikasi MyEG ini membolehkan mereka mengetahui maklumat berkenaan aplikasi ini dan sekali gus membantu mereka menggunakan perkhidmatan dalam talian dengan lebih yakin dan konsisten. Masyarakat sangat digalakkan untuk menggunakan teknologi baharu yang diperkenalkan supaya mereka dapat memperoleh manfaat dari teknologi tersebut.

Di samping itu juga, kewujudan aplikasi MyEG turut membantu golongan perniagaan dalam mempromosikan syarikat masing-masing yang berkaitan dengan penggunaan aplikasi MyEG. Ini difokuskan kepada pihak pembekal perkhidmatan dan syarikat-syarikat rangkaian yang terlibat. Pihak-pihak ini dapat membuat promosi lebih besar-besaran mengenai aplikasi MyEG supaya semua masyarakat dapat menggunakan perkhidmatan tersebut. Antaranya ialah dengan menggunakan media elektronik dengan membuat iklan promosi yang lebih menarik bagi mempromosikan aplikasi MyEG ini. 


\section{BIODATA}

Syafila Kamarudin adalah pelajar Doktor Falsafah Pemajuan Desa di Institut Pengajian Sains Sosial (IPSAS), Universiti Putra Malaysia (UPM). Bidang kajian beliau bertumpu kepada Teknologi Komunikasi dan Pemajuan Luar Bandar (Penggunaan ICT, E-kerajaan dan Perkhidmatan Dalam talian). Emel: syafila.kamarudin@gmail.com

Siti Zobidah Omar merupakan Timbalan Pengarah di Institut Pengajian Sains Sosial (IPSAS), Universiti Putra Malaysia (UPM). Beliau juga merupakan Profesor Madya di Jabatan Komunikasi, Fakulti Bahasa Moden dan Komunikasi (FBMK), Universiti Putra Malaysia. Bidang pengkhususan beliau tertumpu kepada Teknologi Komunikasi dan Budaya (Penggunaan ICT, Telefon bimbit, E-komuniti, ICT dan Jantina). Emel: zobidah@upm.edu.my 


\section{RUJUKAN}

Ahmad Althunibat, Nor Azan Mat Zin, \& Noraidah Sahari @ Ashaari. (2012).Pemodelan faktor penerimaan perkhidmatan kerajaan mudah alih (M-kerajaan). Jurnal Teknologi Maklumat dan Multimedia Asia-Pasifik, 1(1), 21-37.

Ahmad Syahrul Haniff, M. R., Siti Zobidah, O., \& Muhamad Sham, S. A. (2011). Tahap hubungan antara pelbagai faktor terpilih dengan keinginan menggunakan e-dagang dalam kalangan pengguna internet. Jurnal Pengajian Media Malaysia, 13(2), 11-28.

Ahn, T., Ryu, S., \& Han, I. (2007). The impact of web quality and playfulness on user acceptance of online retailing. Information and Management, 44(3), 263-275.

Ajzen, I. (1991). The theory of planned behavior. Organization Behavior and Human Decision Processes, 50(2), 179-211.

Ajzen, I., \& Fishbein, M. (1980). Understanding attitudes and predicting social behavior. Prentice-Hall.

Almarabeh, T., \& Abuali, A. (2010). A general framework for e-government: Definition maturity challenges, opportunities, and success. European Journal of Scientific Research, 39(1), 29-42.

Al-Shafi, S. H. (2009). Factors affecting e-government adoption in the state of Qatar [Doctorate thesis, Brunel University, London]. Brunel University Research Archive (BURA). http://bura.brunel.ac.uk/handle/2438/6266

Alshehri, M., Drew, S., Alhussain, T., \& Alghamdi, R. (2012, December). The effects of website quality on adoption of e-government service: An empirical study applying UTAUT model using SEM [conference presentation]. 23rd Australasian Conference on Information Systems, Geelong, Australia. http://arxiv.org/ftp/arxiv/papers/1211/

Amin, H., Hamid, M. R. A., Lada, S., \& Anis, Z. (2008). The adoption of mobile banking in Malaysia: The case of Bank Islam Malaysia Berhad (BIMB). International Journal of Business and Society, 9(2), 43-53.

Andre Hasudungan Lubis, Syed Zulkarnain Syed Idrus, \& Asiah Sarji. (2018). ICT usage amongst lecturers and its impact towards learning process quality. Jurnal Komunikasi: Malaysian Journal of Communication, 34(1), 284-299.

Babbie, E. (2007). The practice of social research (10th ed.). Thomson Wadsworth.

Bandura, A. (1999). Social cognitive theory: An agentic perspective. Asian Journal of Social Psychology, 2(1), 21-41.

Bett, B. K., Odhiambo, R. O., \& Orwa, G. O. (2014). Modeling e-learning implementation level for primary schools in Nairobi County through stratified random sampling. Education, $4(5), 108-122$.

Burton, S., Sheather, S., \& Roberts, J. (2003). The effect of actual and perceived performance on satisfaction and behavioral intentions. Journal of Service Research, 5(4), 292-302.

Carlsson, B. (2006). Internationalization of innovation systems: A survey of the literature. Research Policy, 35(1), 56-67.

Chau, P. Y., \& Hu, P. J. H. (2002). Investigating healthcare professionals' decisions to accept telemedicine technology: An empirical test of competing theories. Information \& Management, 39(4), 297-311.

Cheung, W., \& Chang, M. K. (2000). Prediction of Internet and world wide web usage at work: A test of an extended Triandis model. Decision Support Systems, 30(1), 83-101. 
Collier, J. E., \& Bienstock, C. C. (2009). Model misspecification: Contrasting formative and reflective indicators for a model of e-service quality. The Journal of Marketing Theory and Practice, 17(3), 283-293.

Conrad, E. D. (2009). Willingness to use it innovations: A hybrid approach employing diffusion of innovations and technology acceptance models [Unpublished PhD thesis, Southern Illinois University, Carbondale, Illinois, USA]. Open SIUC. http://opensiuc.lib.siu.edu/dissertations/283/

Dasgupta, S., Paul, R., \& Fuloria, S. (2011). Factors affecting behavioral intentions towards mobile banking usage: Empirical evidence from India. Romanian Journal of Marketing, 3(1), 6-28.

Davis, F. D. (1989). Perceived usefulness, perceived ease of use, and user acceptance of information technology. MIS Quarterly, 13(3), 319-340.

Davis, F. D., Bagozzi, R. P., \& Warshaw, P. R. (1992). Extrinsic and intrinsic motivation to use computers in the workplace. Journal of Applied Social Psychology, 22(14), 1111-1132. https://doi.org/10.1111/j.1559-1816.1992.tb00945.x

DeLone, W. H. (1988). Determinants of success for computer usage in small business. Mis Quarterly, 12(1), 51-61.

Ismail Sheikh Yusuf Ahmed Dhaha, \& Ali Yassin Sheikh Ali. (2014). Mediating effects of behavioral intention between $3 g$ predictors and service satisfaction. Jurnal Komunikasi: Malaysian Journal of Communication, 30(Special Issue), 107-128. https://doi.org/10.17576/JKMJC-2014-30SI-07

Dillman, D. A. (2000). The role of behavioral survey methodologists in national statistical agencies. International Statistical Review, 68(2), 200-213.

Doucek, P., Fischer, J., \& Novotny, O. (2014). ICT and Economy. 22nd Interdisciplinary Information Management Talks, 55-62.

Fan, Y., Saliba, A., Kendall, E. A., \& Newmarch, J. (2005, July). Speech interface: An enhancer to the acceptance of $m$-commerce application [conference presentation]. International Conference on Mobile Business, Sydney, Australia (pp. 445-451). https://doi.org/10.1109/ICMB.2005.97

Fathilah Ismail, \& Zaharul Nizal Zabidi. (2006). Statistik untuk pengurusan dan ekonomi: Satu pengenalan. Kolej Universiti Sains dan Teknologi Malaysia.

Gardner, C., \& Amoroso, D. L. (2004). Development of an instrument to measure the acceptance of internet technology by consumers. Proceeding 37 International Conference on System Sciences, Hawaii, 5-8 Januari 2004 (pp. 1-10). IEEE Computer Society.

Gattiker, U. E. (1984). Managing computer-based office information technology: A process model for management. Human Factors in Organizational Design, North-Holland, Amsterdam, the Netherlands, 1(1), 395-403.

Gummerus, J., Liljander, V., Pura, M., \& Van Riel, A. (2004). Customer loyalty to content-based web sites: the case of an online health-care service. Journal of Services Marketing, 18(3), 175-186.

Gurung, A. (2006). Empirical investigation of the relationship of privacy security and trust with behavioral intention to transact in e-commerce [Unpublished PhD thesis, University of Texas, Arlington, Texas]. https://uta-ir.tdl.org/uta-ir/bitstream/handle/10106/62/ 
Hamizah Sahharon, Siti Zobidah Omar, Jusang Bolong, Hayrol Azril Mohamed Shaffril, \& Jeffrey Lawrence D'Silva. (2014, June). Social media and adapting social cohesiveness through 1Malaysia wireless village programme: A conceptual framework [conference presentation]. 2nd International Conference on Social Sciences Research (ICSSR 2014), 9-10 June 2014, Kota Kinabalu, Sabah, Malaysia (pp. 186-195). http://psasir.upm.edu.my/id/eprint/38804

Hasmiah Kasimin, Siti Hajar Mohd Idris, \& Noraidah Sahari @ Ashaari. (2011). Kesedaran dan penggunaan perkhidmatan awam dalam talian di kalangan berbagai golongan rakyat. Persidangan Kebangsaan Ekonomi Malaysia ke VI, Melaka, 5-7 Jun 201 (pp. 193-202) http://www.ukm.my/fep/perkem/pdf/perkemVI/PERKEM2011-1-2A4.pdf

Hasmiah Kasimin, Siti Hajar Mohd Idris, \& Noraidah Sahari @ Ashaari. (2013). Pembangunan dan perlaksanaan perkhidmatan eKerajaan: Analisis amalan ekerajaan berpusat rakyat dari perspektif ANT (Actor Network Theory). Jurnal Ekonomi Malaysia, 47(2), 39-54.

Hazita Azman, Ali Salman, Norizan Abdul Razak, Supyan Hussin, Mohd Safar Hasim, \& Musa Abu Hassan. (2014). Determining digital maturity among ICT users in Malaysia. Jurnal Komunikasi: Malaysian Journal of Communication, 30(1), 23-35.

Hong, S., Thong, J. Y., \& Tam, K. Y. (2006). Understanding continued information technology usage behavior: A comparison of three models in the context of mobile internet. Decision Support Systems, 42(3), 1819-1834.

Hung, S. Y., Chang, C. M., \& Yu, T. J. (2006). Determinants of user acceptance of the government services: The case of online tax filling and payment systems. Government Information Quarterly, 23(1), 97-122.

Jabatan Perangkaan Malaysia. (2017, Oktober 9). Laporan penyiasatan pendapatan isi rumah dan kemudahan asas 2016. https://www.dosm.gov.my/v1/index.php? $r=$ column/

Jiang, J. J., Hus, M. K., Klein, G., \& Lin, B. (2000). E-commerce User Behavior Model: An Empirical Study. Human Systems Management, 19(4), 265-276.

Jones, E., Sundaram, S., \& Chin, W. (2002). Factors leading to sales force automation use: A longitudinal analysis. Journal of Personal Selling \& Sales Management, 22(3), 145-157.

Joshua, A. J., \& Koshy, M. P. (2011). Usage patterns of electronic banking services by urban educated customers: Glimpses from India. Journal of Internet Banking and Commerce, 16(1), 1-12.

Kaylor, C., Deshazo, R., \& Van Eck, D. (2002). Gauging e-government: A report on implementing services among American cities. Government Information Quarterly, 18(4), 293-307.

Kijsanayotin, B., Pannarunothai, S., \& Speedie, S. M. (2009). Factors influencing health information technology adoption in Thailand's community health centers: Applying the UTAUT model. International Journal of Medical Informatics, 78(6), 404-416.

Kripanont, N. (2007). Using technology acceptance model to investigate academic acceptance of the Internet. Journal of Business Systems, Governance, and Ethics, 2(1), 13-28.

Laukkanen, T. (2007). Internet vs mobile banking: Comparing customer value perceptions. Business Process Management Journal, 13(6), 788-797.

Lee, J. (2004). Factors affecting intention to use online financial services (Unpublished PhD thesis, The Ohio State University, Columbus, Ohio, United State). https://etd.ohiolink.edu/apexprod/rws etd/send file/ 
Li, W. Z., \& Jiao, A. Y. (2008, October). The impact of website and offline equality on relationship quality: An empirical study on e-retailing [conference presentation]. 4th International Conference on Wireless Communications, Networking and Mobile Computing (WiCOM), Dalian, China (pp. 1-5). https://doi.org/bh2fnx

Lu, J., Yu, C., \& Liu, C. (2009). Facilitating conditions, wireless trust and adoption intention. Journal of Computer Information Systems, 46(1), 17-24.

Luarn, P., \& Lin, H. H. (2005). Toward an understanding of the behavioral intention to use mobile banking. Computers in Human Behavior, 21(6), 873-891. https://doi.org/10.1016/j.chb.2004.03.003

Maimunah, I. (2000). Pengembangan: Implikasi ke atas pembangunan masyarakat. Dewan Bahasa dan Pustaka.

Maizatul Haizan Mahbob, Mohammed Zin Nordin, Ali Salman, Wan Idros Wan Sulaiman, \& Mohd. Yusof Abdullah. (2011). Government to citizen: Advocacy of government online systems and their acceptance among citizens. The Innovation Journal: The Public Sector Innovation Journal, 16(3), 1-13.

Maizatul Haizan Mahbob, Mohammed Zin Nordin, \& Wan Idros Wan Sulaiman. (2012). Inovasi perkhidmatan awam Malaysia melalui pelaksanaan E-Kerajaan: Satu kajian empirik tentang penerimaan e-servis di Lembah Klang. Jurnal Komunikasi: Malaysian Journal of Communication, 27(1), 18-33.

Malhotra, Y., \& Galetta, D. (1999, January). Extending the technology acceptance model to account for social influence: Theoretical bases and empirical validation [conference presentation]. 32nd Hawaii International Conference on System Sciences, USA. https://doi.org/10.1109/HICSS.1999.772658

MAMPU (Unit Pemodenan Tadbiran dan Perancangan Pengurusan Malaysia). (2011). Transaksi perkhidmatan dalam talian. https://www.mampu.gov.my/ms/

Marchewka, J. T., Liu, C., \& Kostiwa, K. (2007). An application of the UTAUT model for understanding student perceptions using course management software. Communications of the IIMA, 7(2), 93-104.

May, H. (2004). Making statistics more meaningful for policy research and program evaluation. American Journal of Evaluation, 25(4), 525-540.

Michael, S. M., \& Prabowo, P. W. (2011). Kajian unified theory of acceptance and use of technology dalam penggunaan open source software management system: Studi kasus Universitas Indraprasta PGRI. Jurnal IImiah Program Pascasarjana Magister IImu Komputer STMIK Nusa Mandiri, 1(1), 1-9.

Miyamoto, M., Kudo, S., \& lizuka, K. (2012). Measuring ERP success: Integrated model for user satisfaction and technology acceptance; An empirical study in Japan [conference presentation]. International Conference on Business, Management and Governance (ICBMG2012) (pp. 86-91). http://www.ipedr.com/vol57/

Mohd Khairie Ahmad, Mohd Baharudin Mohd Hadza @ Othman, Suhaini Muda, \& Mohd Hafidz Hussien. (2005). Kredibiliti berita akhbar televisyen, radio dan berita dalam talian (Unpublished, Laporan Penyelidikan Geran Universiti, Fakulti Komunikasi dan Bahasa Moden, Universiti Utara Malaysia). http://repo.uum.edu.my/5961/

Mohd Nizam Osman. (2018). ICT Innovation, adoption and diffusion: An exploratory analysis on usage patterns for economic productivity. Jurnal Komunikasi: Malaysian Journal of Communication, 22(2006), 135-153.

Mohd Safar Hasim, \& Ali Salman. (2010). Factors affecting sustainability of internet usage among youth. The Electronic Library, 28(2), 300-313. 
Muhammad Rais, A. K., \& Nazariah, M. K. (2003). E-government in Malaysia. Pelanduk Publications.

Nelson, R., Todd, P., \& Wixom, B. (2005). Antecedents of information and system quality: An empirical examination within the context of data warehousing. Journal of Management Information Systems, 21(4), 199-235.

Neuman, W. L. (2007). Basics of social research: Quantitative and qualitative approaches (2nd ed.). Allyn and Bacon.

Nik Adzrieman Abd Rahman. (2017). Electronic propinquity in the hospital management system among ICT integrated hospitals in Malaysia. Jurnal Komunikasi: Malaysian Journal of Communication, 33(3), 125-139.

Nor Aliah Mohd Zahri. (2012, July). The digital content for the malaysian public sector. Persidangan National Digital, Putrajaya International Convention Centre (PICC), Putrajaya, Malaysia.

Nor Aliah Mohd Zahri. (2011, November). New economy of ICT empowering public sector digital transformation (Kertas Ucaptama). Persidangan CIO Malaysia dan MyGOSSCON, Putrajaya International Convention Centre (PICC), Putrajaya, Malaysia.

Noraidah Sahari @ Ashaari, Norashikin Zainal Abidin, Emy Salfarina Alias, Hasmiah Kasimin, \& Siti Hajar Mohd Idris. (2011, June). Kemudahan capaian dan penggunaan e-kerajaan di Malaysia. Persidangan Kebangsaan Ekonomi Malaysia ke VI (PERKEM VI) (pp. 173180). https://www.ukm.my/fep/perkem/pdf/perkemVI/PERKEM2011-1-2A2.pdf

Norashikin Zainal Abidin, Noraidah Sahari @ Ashaari, Hasmiah Kasimin, \& Siti Hajar Mohd Idris. (2011, June). E-kerajaan: Ke arah mewujudkan budaya e-pengguna dalam kalangan rakyat Malaysia. Persidangan Kebangsaan Ekonomi Malaysia ke VI (pp. 181-192). http://www.ukm.my/fep/perkem/pdf/perkemVI/PERKEM2011-1-2A3.pdf

Norashuha Tajuddin, Hamdan Said, Ros Ilyani Rosdi, Nguyen Thuy Van, Tee Tiam Chai, Mohd Rustam Mohd Rameli, Noriadah Abdul Karim. (2013, November). Keperluan medium perkhidmatan dalam talian dalam pelaksanaan penasihatan akademik (seminar presentation paper). 2nd International Seminar on Quality and Affordable Education (ISQAE 2013). https://humanities.utm.my/education/wp-content.pdf

Norshita, M. N., Halimah, B. Z., \& Tengku Mohammad, T. S. (2010, May). E-kerajaan: Analisis konsep dan pelaksanaan di Malaysia [conference presentation]. Regional Conference on Knowledge Integration in ICT, Malaysia.

Ozgen, F. B., \& Turan, A. H. (2007, September). Usage and adoption of online tax filing and payment system in tax management: An empirical assessment with technology acceptance (TAM) model in Turkey [conference presentation]. 9th International Scientific Conference, Management Horizons: Visions and Challenges, Vytautas Magnus University, Kaunas.

Parasuraman, A., Zeithaml, V. A., \& Malhotra, A. (2005). E-S-Qual: A multiple-item scale for assessing electronic service quality. Journal of Service Research, 7(3), 213-233.

Park, J., Yang, S., \& Lehto, X. (2007). Adoption of mobile technologies for Chinese consumers. Journal of Electronic Commerce Research, 8(3), 196-206.

Prasetyo, H. B., \& Anubhakti, D. (2011). Kajian penerimaan sistem e-learning dengan menggunakan pendekatan UTAUT studi kasus Fakultas Teknologi Informasi Universitas Budi Luhur. Jurnal BIT, 8(2), 45-47. 
Puschel, J., Mazzon, J. A., \& Hernandez, J. M. C. (2010). Mobile banking: Proposition of an integrated adoption intention framework. International Journal of Bank Marketing, 28(5), 389-409.

Rahmatika, R. (2015). Kajian penerimaan dan penggunaan Coreldraw untuk pembelajaran multimedia. Jurnal Faktor Exacta, 8(2), 116-125.

Raidah Mazuki, Siti Zobidah Omar, Jusang Bolong, Jeffrey Lawrence D. Silva, Musa Abu Hassan, \& Hayrol Azril Mohamed Shaffril. (2013). Social influence in using ICT among fishermen in Malaysia. Asian Social Science, 9(2), 135-138. http://dx.doi.org/10.5539/ass.v9n2p135

Riquelme, H. E., \& Rios, R. E. (2010). The moderating effect of gender in the adoption of mobile banking. International Journal of Bank Marketing, 28(5), 328-341. https://doi.org/b6vgvz

Rogers, E. M. (2004). A prospective and retrospective look at the diffusion model. Journal of Health Communication, 9(1), 13-19.

Rust, R. T., \& Lemon, K. N. (2001). E-service and the consumer. International Journal of Electronic Commerce, 5(3), 85-101.

Schaupp, L. C., Fan, W., \& Belanger, F. (2006, January). Determining success for different website goals [conference presentation]. 39th Hawaii International Conference on System Sciences (HICSS), Kauai, USA. https://doi.org/10.1109/HICSS.2006.122

Shahril Shabudin, Nor Hayati Alwi, Hanafi Atan, \& Su Luan Wong. (2012). Sikap guru sains terhadap penggunaan teknologi komputer di makmal sains. Jurnal Teknologi, 48(1), 169-186.

Shih, Y. Y., \& Fang, K. (2004). The use of a decomposed theory of planned behavior to study Internet banking in Taiwan. Internet Research, 14(3), 213-223. https://doi.org/10.1108/10662240410542643

Singh, S., Srivastava, V., \& Srivastav, R. K. (2010). Customer acceptance of mobile banking: A conceptual framework. SIES Journal of Management, 7(1), 55-64.

Siti Zobidah Omar, Musa Abu Hassan, A. H., Narimah Ismail, \& Jusang Bolong. (2008). Faktor kejayaan dan kegagalan projek ICT di luar bandar. Pertanika Journal of Social Sciences and Humanities, 16(2), 173-186.

SKMM (Suruhanjaya Komunikasi dan Multimedia Malaysia). (2013). Internet users survey 2013. https://www.skmm.gov.my/en/media/announcements/internet-survey-2013

Sripalawat, J., Thongmak, M., \& Ngramyarn, A. (2011). M-banking in metropolitan Bangkok and a comparison with other countries. The Journal of Computer Information Systems, 51(3), 67-76.

Sulaiman, S. (2004). Research methods for the social sciences. DSS Publishing Enterprise.

Sumak, B., Polančič, G., \& Heričko, M. (2010, February). An empirical study of virtual learning environment adoption using UTAUT [conference presentation]. 2010 Second International Conference on Mobile, Hybrid, and On-Line Learning, Saint Maarten, Netherlands Antilles, (pp. 17-22). https://doi.org/10.1109/eLmL.2010.11

Tan, M., \& Teo, T. S. H. (2000). Factors influenching the adoption of Internet banking. Journal of Associations for Information System, 1(5), 1-42.

Taylor, S., \& Todd, P. A. (1995). Understanding information technology usage: A test of competing models. Information Systems Research, 6(2), 144-176.

Thompson, R. L., Higgins, C. A., \& Howell, J. M. (1991). Personal computing: Toward a conceptual model of utilization. MIS Quarterly, 15(1), 125-143. 
Thompson, R. L., Higgins, C. A., \& Howell, J. M. (1994). Influence of experience on personal computer utilization: Testing a conceptual model. Journal of Management Information Systems, 1(1), 167-187.

Triandis, H. C. (1979). Values, attitudes, and interpersonal behavior. Nebraska Symposium on Motivation, 27(1), 195-259.

Venkatesh, V., \& Morris, M. G. (2000). Why don't men ever stop to ask for directions? Gender, social influence and their role in technology acceptance and usage behaviour. MIS Quarterly, 24(1), 115-139.

Venkatesh, V., Morris, M. G., Davis, G. B., \& Davis, F. D. (2003). User acceptance of information technology: Toward a unified view. MIS Quarterly, 27(3), 425-478.

Waring, T., \& Wainwright, D. (2002). Enhancing clinical and management discourse in ICT implementation. Journal of management in Medicine, 16(2/3), 133-149.

Wixom, B., \& Todd, P. (2005). A theoretical integration of user satisfaction and technology acceptance. Information Systems Research, 16(1), 85-102.

Yamane, T. (1967). Elementary sampling theory. Prentice- Hall.

$\mathrm{Yu}, \mathrm{C}$. S. (2012). Factors affecting individuals to adopt mobile banking: Empirical evidence from the UTAUT model. Journal of Electronic Commerce Research, 13(2), 104-121.

Zulkefli Ibrahim, \& Ainin Sulaiman. (2009). The influence of Malaysian telecenters on community building. Electronic Journal of e-Government, 7(1), 77-86. 